Check for updates

Cite this: RSC Adv., 2020, 10, 37391

\title{
Co-digestion of microalgae with potato processing waste and glycerol: effect of glycerol addition on methane production and the microbial community $\dagger$
}

\author{
Yanghanzi Zhang, (D)*a Gary S. Caldwell, ${ }^{\text {b }}$ Philip T. Blythe, ${ }^{a}$ Andrew M. Zealand, ${ }^{c}$ \\ Shuo Li, ${ }^{a}$ Simon Edwards, ${ }^{a}$ Jin Xing, ${ }^{a}$ Paul Goodman, ${ }^{a}$ Paul Whitworth ${ }^{b}$ \\ and Paul J. Sallis ${ }^{a}$
}

\begin{abstract}
The production of methane-rich biogas from the anaerobic digestion (AD) of microalgae is limited by an unfavorable biomass carbon-to-nitrogen $(\mathrm{C} / \mathrm{N})$ ratio; however, this may be ameliorated using a codigestion strategy with carbon-rich feedstocks. For reliable plant operation, and to improve the economics of the process, secure co-feedstock supply (ideally as a waste-stream) is important. To this end, this study investigated the feasibility of co-digesting microalgae (Chlorella vulgaris) with potato processing waste (potato discarded parts, PPW $\mathrm{dp}_{\text {; }}$ potato peel, $\mathrm{PPW}_{\mathrm{p}}$ ) and glycerol, while monitoring the response of the methanogenic community. In this semi-continuous study, glycerol ( 1 and $2 \% \mathrm{v} / \mathrm{v})$ added to mixtures of $C$. vulgaris : PPW dp enhanced the specific methane yields the most, by $53-128 \%$, whilst co-digestion with mixtures of $C$. vulgaris : PPW $_{p}$ enhanced the methane yields by $62-74 \%$. The microbial communities diverged markedly over operational time, and to a lesser extent in response to glycerol addition. The acetoclast Methanosaeta was abundant in all treatments but was replaced by Methanosarcina in the potato peel with glycerol treatment due to volatile fatty acid (VFA) accumulation. Our findings demonstrate that the performance of microalgae co-digestion is substantially improved by the addition of glycerol as an additional co-feedstock. This should improve the economic case for anaerobically digesting microalgae as part of wastewater treatment processes and/or the terminal step of a microalgae biorefinery.
\end{abstract}

Received 13th September 2020

Accepted 28th September 2020

DOI: $10.1039 / d 0 r a 07840 a$

rsc.li/rsc-advances

\section{Introduction}

In 2017, the UK government announced the Industrial Strategy, which set out four Grand Challenges. The Clean Growth Grand Challenge seeks to use low carbon technologies and efficient new materials to encourage the rapid growth of a clean economy. The development of new markets in areas such as smart energy systems and the 'bio-economy' are encouraged to accelerate progress to achieve this identified challenge. ${ }^{1}$ The 'bio-economy' refers to the use of renewable biological resources from land and sea to produce food, materials and energy. The production of renewable energy from biomass resources is one of the important options for sustainable

${ }^{a}$ School of Engineering, Newcastle University, Cassie Building, Claremont Road, Newcastle upon Tyne, NE1 7RU, UK. E-mail: yanghanzi.zhang@newcastle.ac.uk

${ }^{b}$ School of Natural and Environmental Sciences, Newcastle University, Ridley Building, Claremont Road, Newcastle upon Tyne, NE1 TRU, UK

${ }^{c}$ Department of Applied Sciences, Faculty of Health and Life Sciences, Northumbria University, Newcastle upon Tyne NE1 8ST, UK

$\dagger$ Electronic supplementary information (ESI) available. See DOI: 10.1039/d0ra07840a development. Biomass energy in the form of heat, electricity and liquid fuels (biofuels) can be produced from a wide range of biomass sources such as virgin wood, energy crops, agricultural residues and food and industrial waste streams via various conversion processes. ${ }^{2}$ Microalgae have a number of advantages over conventional biomass, including high productivity, lower lignin content, less land requirement and high photosynthetic efficiency. ${ }^{3,4}$ There is growing interest in the mass production of microalgae for a range of biotechnology and bioengineering applications, ranging from the extraction of individual chemicals to the use of the entire biomass, often for fuels or environmental remediation activities. ${ }^{5}$ However, growing microalgae specifically for low value, high volume products such as biodiesel is well documented as being economically unfeasible using current culture and processing practices. ${ }^{6}$ Alternative approaches to valorising microalgae biomass have concentrated on developing more diverse business models, with the biomass contributing multiple income streams commonly referred to as a biorefinery concept., ${ }^{3,7}$ A simpler scenario could involve microalgae contributing an ecosystem service during growth, e.g. remediating excess nutrients in 
a wastewater treatment process, with the resulting biomass processed for additional products. ${ }^{\mathbf{8} 9}$ Anaerobic digestion (AD) is one such downstream process; indeed, in addition to $\mathrm{AD}$ improving the overall energy balance of wastewater treatment processes. ${ }^{10} \mathrm{AD}$ is argued as a vital step in improving the economic case for microalgae biodiesel production. ${ }^{11}$

$\mathrm{AD}$ is a robust biochemical conversion process whereby macromolecules (carbohydrates, proteins and lipids) can be degraded by anaerobic microorganisms to generate methanerich biogas, with the digestate potentially used as a nutrient fertilizer in agriculture. ${ }^{12}$ However, microalgae biomass is rich in protein which may contribute to an unbalanced carbon-tonitrogen $(\mathrm{C} / \mathrm{N})$ ratio (typically within a range of 4.65 to 17$)$, which is lower than the optimum range of 20 to 30 for AD. ${ }^{13-16}$ This imbalance may destabilise the $\mathrm{AD}$ process and reduce methane production, particularly if microalgae are used as a mono-digestion feedstock. Anaerobic co-digestion of two or more complementary feedstocks may cause a synergistic effect on their biodegradability, enhancing methane production. ${ }^{\mathbf{1 7}}$ Microalgae have been reported to co-digest effectively with carbon-rich feedstocks such as waste paper and maize, thereby rebalancing the $\mathrm{C} / \mathrm{N}$ ratio and increasing methane production. ${ }^{\mathbf{1 4 1 8 , 1 9}}$ To further support the economic case for digesting microalgae, any carbon-rich feedstocks should come as wastestreams rather than be produced specifically for bioenergy production. Potato processing waste (PPW) is a main by-product of industrial potato processing such as manufacturing French fries, canned foods and starch products. PPW is rich in soluble organic matter, and its $\mathrm{C} / \mathrm{N}$ ratio ranges from 12.1 to $30.0 .^{20,21}$ Therefore, co-digestion with PPW is another option to improve methane production from microalgae. Previously, we demonstrated stable co-digestion of a freshwater microalga (Chlorella vulgaris) and a marine microalga (Tisochrysis lutea) with PPW in batch and semi-continuous modes., ${ }^{4,22}$ However, reliance on a single waste-stream could pose some operational risks to an $\mathrm{AD}$ plant, ${ }^{23}$ furthermore in order to improve the economics of the process, secure co-feedstock supply is important. Therefore, in the current study we introduce an additional level of feed complexity by including glycerol as a secondary co-digestion feedstock.

Glycerol is a main by-product of biodiesel production representing $10 \% \mathrm{w} / \mathrm{w}$ of the total product stream. ${ }^{24-26}$ By 2028, total global biodiesel production is predicted to reach 44 million tonnes, generating 4.4 million tonnes of glycerol. ${ }^{27}$ The rapid growth of the biodiesel industry has led to overproduction of crude glycerol and glycerol disposal is associated with environmental concerns. ${ }^{28}$ An alternative to disposal, which concomitantly mitigates its surplus production, is to convert the glycerol to other valuable products. Glycerol contains high concentrations of chemical oxygen demand (COD) and is easily degraded by acidogenic bacteria to produce organic acids. ${ }^{29-31}$ Therefore, glycerol is a potential feedstock for anaerobic codigestion with low carbon feedstocks such as pig manure and, mixtures of strawberry and fish waste. ${ }^{32-34}$ Glycerol was also introduced to co-digest with algal biomass to boost methane production. For instance, Oliveira et al. (2015) investigated that co-digestion of macroalgae Sargassum sp. with glycerol and waste frying oil to improve methane production in batch BMP test. $^{35}$ Their results showed that the addition of glycerol to these two feedstocks increased methane yields by $56 \%$. Neumann et al. (2015) investigated that anaerobic co-digestion of $90 \%$ lipid-spent microalgae Botryococcus braunii with $10 \%$ glycerol in batch BMP tests, it was found that methane yields slightly increased compared to digestion with mono-substrate. ${ }^{36}$ However, the methane production rates were not significantly enhanced. $\mathrm{AD}$ of whole microalgae seems to be an optimum strategy in terms of energy balance if the microalgal cell-lipid composition is less than $40 \%{ }^{11}$ Therefore, glycerol is also considered to be a potential feedstock for microalgae codigestion although there is little information available about co-digestion of whole microalgae with glycerol. Moreover, in order to avoid some potential AD plant's operational risks that caused by a single waste-stream co-substrate, the effect of microalgae co-digestion with PPW and glycerol on methane production needs to be evaluated.

Although many studies have reported the co-digestion of PPW or glycerol with other feedstocks, information on anaerobic co-digestion of microalgae with PPW and glycerol is limited; this is an important knowledge gap within the context of microalgae biorefineries given the likely incidental increase in glycerol production from transesterification as biodiesel from microalgae becomes a commercial reality. ${ }^{7,37}$ In addition, previous microalgae co-digestion studies mostly focused on evaluating the effects of environmental factors on the stability of the co-digestion process, ${ }^{19}$ few have assessed the impact on the microbial community. The current study aimed to enhance methane production from microalgae by co-digestion with PPW and glycerol. For semi-continuous co-digestion studies, the effect of glycerol dosage on methane production, process stability and microbial diversity/structural dynamics was investigated.

\section{Methods and materials}

\subsection{Microalgae and co-substrates}

Chlorella vulgaris strain (CCAP 211/63) was used in this study, and detailed information of cultivation and harvesting of microalgae were described by previous studies. ${ }^{22,38}$ Two categories of PPW were prepared; discarded parts $\left(\mathrm{PPW}_{\mathrm{dp}}\right)$ and peel $\left(\mathrm{PPW}_{\mathrm{p}}\right)$. The detailed information of preparation of two PPW feedstocks $\left(\mathrm{PPW}_{\mathrm{dp}}\right.$ and $\left.\mathrm{PPW}_{\mathrm{p}}\right)$ were described by previous studies. ${ }^{\mathbf{4} 22}$ The feedstocks of $C$. vulgaris, $\mathrm{PPW}_{\mathrm{dp}}$ and $\mathrm{PPW}_{\mathrm{p}}$ were characterised for their total solids (TS), volatile solids (VS), total chemical oxygen demand $\left(\mathrm{COD}_{\mathrm{t}}\right)$, and carbohydrate and protein content as well as $\mathrm{C}$ and $\mathrm{N}$ content.

The anaerobic seed inoculum was collected from a manurebased farm anaerobic digester located at the University owned Cockle Park Farm, Northumberland, UK. The characteristics of Chlorella vulgaris, PPW and seed inoculum are summarized in Table 1.

A glycerol solution (Sigma-Aldrich, 4978, UK) with a purity of $86-89 \%$ was used as a co-substrate. The glycerol solution had a $\mathrm{COD}_{\mathrm{t}}$ of $1888.0 \pm 2.8 \mathrm{~g} \mathrm{~L}^{-1}$ and density of $1.25 \mathrm{~kg} \mathrm{~L}^{-1}$. 
Table 1 Feedstock and inoculum characteristics

\begin{tabular}{lrlll}
\hline & C. vulgaris & $\mathrm{PPW}_{\mathrm{dp}}{ }^{a}$ & $\mathrm{PPW}_{\mathrm{p}}{ }^{b}$ & Inoculum \\
\hline TS $\left(\mathrm{g} \mathrm{L}^{-1}\right)$ & $2.7 \pm 0.2^{c}$ & $16.0 \pm 0.4$ & $15.7 \pm 0.1$ & $18.6 \pm 1.2$ \\
VS $\left(\mathrm{g} \mathrm{L}^{-1}\right)$ & $2.4 \pm 0.1$ & $14.8 \pm 0.4$ & $13.9 \pm 0.1$ & $10.4 \pm 0.9$ \\
VS/TS (\%) & $88.9 \pm 3.2$ & $92.2 \pm 0.1$ & $88.7 \pm 0.1$ & $56.1 \pm 0.9$ \\
COD $_{\mathrm{t}}\left(\mathrm{g} \mathrm{L}^{-1}\right)$ & $3.5 \pm 0.3$ & $13.8 \pm 0.2$ & $12.5 \pm 0.1$ & n.a. \\
Proteins (\% VS) & $37.6 \pm 4.0$ & $13.0 \pm 0.2$ & $13.7 \pm 1.1$ & n.a. \\
Carbohydrates (\% VS) & $23.8 \pm 3.3$ & $74.8 \pm 0.1$ & $69.0 \pm 3.7$ & n.a. \\
C/N & 6.4 & 40.8 & 28.6 & n.a.
\end{tabular}

${ }^{a} \mathrm{PPW}_{\mathrm{dp}}$ : potato discarded parts. ${ }^{b} \mathrm{PPW}_{\mathrm{p}}$ : potato peel. ${ }^{c}$ Mean $\pm \mathrm{SD}, n=$ 2. ${ }^{d}$ n.a.: not analysed.

\subsection{Operation of semi-continuous anaerobic digesters}

Eight identical one litre Duran bottles (VWR, UK) with a working volume of $0.8 \mathrm{~L}$ were used as the semi-continuous codigestion digesters, and detailed information of the digester configuration was described by Zhang et al. (2019). ${ }^{4}$ At the beginning of the experiment, all digesters were filled with $0.8 \mathrm{~L}$ of anaerobic inoculum, and flushed with $\mathrm{N}_{2}$ to ensure anaerobic conditions. The semi-continuous digesters were kept at constant temperature of $37{ }^{\circ} \mathrm{C}$ by a temperature-controlled water-bath. The digester was mixed by hand mixing before and after feeding.

The semi-continuous digesters were studied at four feeding conditions: the digesters were fed with mixtures of $C$. vulgaris : $\mathrm{PPW}_{\mathrm{dp}}$ and glycerol (C1); mixtures of $C$. vulgaris: $\mathrm{PPW}_{\mathrm{dp}}$ without glycerol (C2); mixtures of $C$. vulgaris: $\mathrm{PPW}_{\mathrm{p}}$ and glycerol (C3); and mixtures of $C$. vulgaris : $\mathrm{PPW}_{\mathrm{p}}$ without glycerol (C4). All digesters were fed every day during period I and every two days for the rest of periods. The hydraulic retention time (HRT) was set at 20 days with an overall operation time of 76-132 days. Detailed information of variation of organic loading rates (OLRs) and feedstock composition over the co-digestion process is summarized in Table 2. During period I, all digesters were fed with $100 \%$ $\mathrm{PPW}_{\mathrm{dp}}$ or $100 \% \mathrm{PPW}_{\mathrm{p}}$. In period II, all digesters were fed a mixture of $25 \%$ C. vulgaris and $75 \% \mathrm{PPW}_{\mathrm{dp}}$ or $75 \% \mathrm{PPW}_{\mathrm{p}}$ based on the proportion of VS. A 25 : 75 ratio of $C$. vulgaris and PPW had the potential to provide an optimum $\mathrm{C} / \mathrm{N}$ ratio and produce high methane yields compared to other tested mixing ratios (e.g. $75: 25$ and $50: 50$ ) as discussed by Zhang et al. (2019). ${ }^{22}$ Digesters C1 and C3 were also fed with glycerol, and the dosage of glycerol in the mixture was progressively increased from 1 to $2 \% \mathrm{v} / \mathrm{v}$ over period II. The glycerol dosages of 1 and $2 \% \mathrm{v} / \mathrm{v}$ were selected based on previous studies on anaerobic co-digestion of glycerol with other low carbon feedstocks. ${ }^{29,30}$ Periods III and IV are the experimental phases for digesters $\mathrm{C} 1$ and $\mathrm{C} 2$, where digester $\mathrm{C} 1$ was supplemented with different glycerol dosages, i.e., 2 and $1 \% \mathrm{v} / \mathrm{v}$ for periods III and IV, respectively. Digester $\mathrm{C} 2$ was used as control digester, and fed with $25: 75 C$. vulgaris : $\mathrm{PPW}_{\mathrm{dp}}$ without glycerol supplementation. Overall, digesters $\mathrm{C} 1$ and $\mathrm{C} 2$ were operated 76 days.

Table 2 Organic loading rate (OLR) and feedstock composition for co-digesting C. vulgaris and potato processing waste (PPW) with or without glycerol

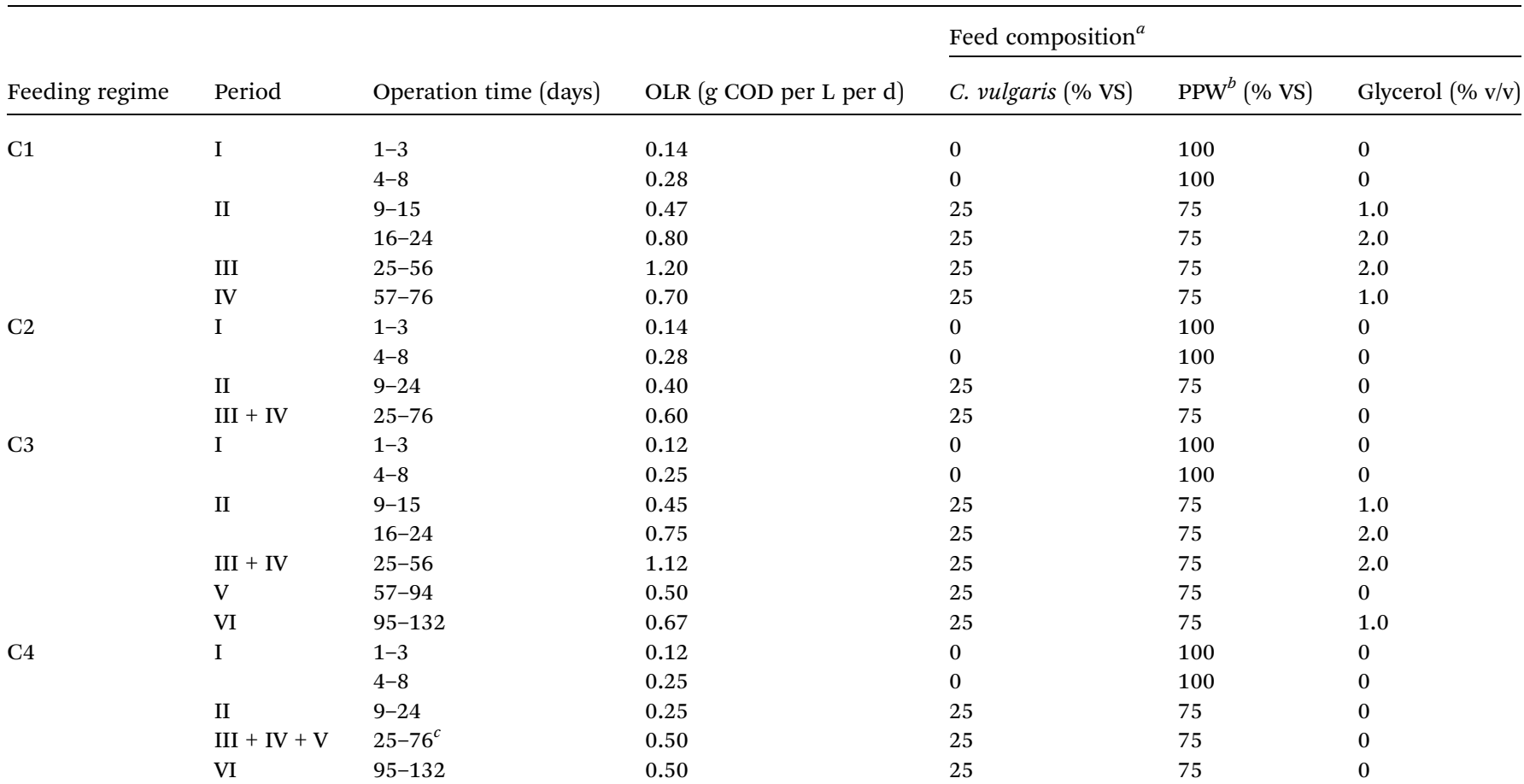

${ }^{a} 25 \%$ C. vulgaris mixed with $75 \% \mathrm{PPW}_{\mathrm{dp}}$ or $\mathrm{PPW}_{\mathrm{p}}$ had C/N ratios of 22.8 and 19.9 , respectively. ${ }^{b}$ Digesters C1 and C2 were fed with potato discarded parts $\left(\mathrm{PPW}_{\mathrm{dp}}\right)$; digesters $\mathrm{C} 3$ and $\mathrm{C} 4$ were fed with potato peel $\left(\mathrm{PPW}_{\mathrm{p}}\right) .{ }^{c}$ During the recovery stage (from days 57 to 94 ), digester $\mathrm{C} 4$ was unfed for a period (days 77 to 94 ). 
For digesters $\mathrm{C} 3$ and $\mathrm{C} 4$, the operating phases started from periods III to VI. During periods III and IV, digester C3 was supplemented with $2 \% \mathrm{v} / \mathrm{v}$ of glycerol, but had no glycerol supplementation in period V. Glycerol was back to add to digester C3 at 1\% v/v during period VI. Control digester C4 was only fed with $25: 75$ C. vulgaris : $\mathrm{PPW}_{\mathrm{p}}$. Overall, digesters C3 and $\mathrm{C} 4$ were operated for 132 days.

During the semi-contiguous co-digestion process, biogas yield, methane content, and $\mathrm{pH}$ values were measured every feeding day. Digestate samples were collected weekly and analysed for TS, VS, the concentrations of total chemical oxygen demand $\left(\mathrm{COD}_{\mathrm{t}}\right)$, soluble chemical oxygen demand $\left(\mathrm{COD}_{\mathrm{s}}\right)$, total alkalinity (TA), volatile fatty acids (VFAs), ammonium nitrogen $\left(\mathrm{NH}_{4}{ }^{+}-\mathrm{N}\right)$ and free ammonia nitrogen (FAN).

\subsection{Analytical methods}

The TS and VS of feedstocks and digester samples were determined according to APHA standard methods. ${ }^{39}$ Concentrations of $\mathrm{COD}_{\mathrm{t}}$ and $\mathrm{COD}_{\mathrm{s}}$ were measured using Merck Millipore COD cell test kits (VWR, UK) based on the standard methods of APHA $5220 \mathrm{D} .{ }^{39}$ To obtain the soluble phase, samples were centrifuged at $3392 \times g$ for 10 minutes and then filtered using a $0.2 \mu \mathrm{m}$ nylon filter (VWR, UK). Feedstocks' carbohydrate content was measured via the phenol-sulfuric acid method, with D-glucose as a standard. ${ }^{40}$ Feedstocks' protein content was measured using a bicinchoninic acid (BCA) protein assay kit (Thermo Scientific Pierce, UK), using bovine serum albumin as the standard. For analysis of $\mathrm{C}$ and $\mathrm{N}$ content, feedstocks were oven dried at $60{ }^{\circ} \mathrm{C}$ until constant weight and analysed by using an Elementar VarioMAX CNS analyzer (Elementar, Germany). Concentration of $\mathrm{NH}_{4}{ }^{+}-\mathrm{N}$ of digester samples was measured using Merck ammonium cell test kits (VWR, UK) based on the standard methods of APHA $4500-\mathrm{NH}_{3} \mathrm{~F}^{39} \mathrm{pH}$ was measured using a Jenway $3010 \mathrm{pH}$-meter (Jenway, UK), and FAN was calculated using eqn (1): ${ }^{41}$

$$
\mathrm{FAN}=\frac{\mathrm{NH}_{4}{ }^{+}-\mathrm{N} \times 10^{\mathrm{pH}}}{\mathrm{e}^{6344 /(273+T)}+10^{\mathrm{pH}}}
$$

The total alkalinity (TA) and total VFAs concentrations were determined via titration with $0.1 \mathrm{~N}$ sulphuric acid as standard. ${ }^{42}$ The measurement of the individual concentrations of VFAs, samples were first diluted and then filtered using a $0.2 \mu$ m nylon filter (VWR, UK). Then, the filtered sample was mixed with $0.1 \mathrm{M}$ octane sulphonic acid at a ratio of $1: 1$ before sonicating for 40 minutes. The VFAs were than measured by an Ion Chromatography (Dionex ICS-1000) equipped with an Ionpack ICE ASI column, with heptafluorobutyric acid as the eluent and tetrabutylammonium hydroxide as the regenerant. The IC also equipped with an AS-AP auto sampler and a Chameleon 7 Software to analyse the sonicated samples.

Gasbags (1 L) (Sigma-Aldrich, UK) were used for biogas collection from the digesters. On each measurement day, the gasbags were disconnected and biogas volume immediately quantified using a $500 \mathrm{~mL}$ jumbo gastight syringe (SGE, 500MAR-LL-GT). Methane content was analysed by gas chromatography. Subsequently, the gasbags were emptied and reconnected to the digesters. The methane composition were analysed by gas chromatography (Carlo-Erba 5160 GC with MFC 500 detector) in split mode with the injector at $150{ }^{\circ} \mathrm{C}$ and FID at $300{ }^{\circ} \mathrm{C}$. The GC fitted with an Agilent HP-PLOTQ column (0.32 mm diameter, $30 \mathrm{~m}$ length and $20 \mu \mathrm{m}$ film, Agilent, UK), and carrier gas was hydrogen $\left(250 \mathrm{~mL} \mathrm{~min}^{-1}\right)$ with an oven temperature held at $35^{\circ} \mathrm{C}$. At the beginning, triplicate injections of $50,40,30,20$ and $10 \mu \mathrm{L}$ of methane standards $(10 \%$ or $80 \%$ balanced with $\mathrm{CO}_{2}$; Scientific and Technical Gases Ltd., UK) to derive a standard curve. A minimum calibration coefficient $\left(R^{2}\right)$ of 0.99 is required before the analysis of test gas samples. After that, triplicate injections of a $50 \mu \mathrm{L}$ of test sample, taken from the gas bags of the semi-continuous digesters using a $100 \mu \mathrm{L}$ gastight syringe (SGE, 100R-V-GT), were qualified by reference to the standard curve. The volume of methane was calculated under STP conditions $\left(0{ }^{\circ} \mathrm{C}, 1 \mathrm{~atm}\right)$.

\subsection{Microbial analysis}

For microbial community analysis, genomic DNA from samples of the semi-continuous digesters and the negative control were extracted using an isolation kit (DNeasy PowerSoil kit, QIAGEN, UK) following the manufacturer's instructions. After extraction, the quality of DNA samples were determined using a DeNovix spectrophotometer (DeNovix, US) measuring the absorbance at 260 and $280 \mathrm{~nm}$. The extracted total DNA samples were sent for paired-end Illumina MiSeq sequencing of the V4 hypervariable region of $16 \mathrm{~S}$ rRNA. The basic processes for Illumina MiSeq sequencing are library preparation, cluster amplification, sequencing and alignment and data analysis. The universal primers set 515F and 806R were used to allow amplification of the V4 region of both bacteria and archaea. ${ }^{43}$ The amplicon libraries were sequenced on the Illumina MiSeq platform using the Wet Lab SOP as described by Kozich et al. (2013). ${ }^{44}$ At the end, FASTQ files with quality score encoding were generated. The raw Illumina FASTQ files were demultiplexed and quality filtered using QIIME 2 with plugin wraps DADA 2 (https:// docs.qiime2.org/2018.4/). Sequences presenting at 99\% similarity were grouped into one operational taxonomic unit (OTU), and assigned taxonomy from the SILVA 119 reference database. The processed sequencing data were further analysed to check microbial diversity using the phyloseq package in RStudio. ${ }^{45}$

\subsection{Statistical analysis}

The independent Samples $t$-test and one-way analysis of variance (ANOVA) were utilized to test the effects of glycerol dose on the significance of methane production and digester performance by co-digestion of $C$. vulgaris and PPW using IBM SPSS statistics, version $23 .{ }^{46}$ Microbial alpha diversity of observed OTU numbers, Shannon's and Simpson's indices were plotted using phyloseq and ggplot2 packages in RStudio (version 3.5.3). Significant differences in alpha diversity between the operation time and glycerol addition were compared by means of ANOVA (aov function). Principal coordinate analysis (PCoA) was performed to examine the microbial beta diversity based on BrayCurtis distance measures. Significant differences in beta 
diversity between the operation time and glycerol addition were identified by means of pair-wise permutational multivariate analysis of variance (PERMANOVA) with Bonferroni correction, using phyloseq and RVAideMemoire packages in RStudio (version 3.5.3). The independent Samples $t$-test was utilized to test the effect of glycerol dose on the significance of relative abundance of bacterial community, using IBM SPSS (version 23). ${ }^{46}$ A Spearman's rank-order correlation was run to determine the relationship between the relative abundance of methanogenic archaea and digester operating parameters, using IBM SPSS (version 23) ${ }^{46}$ A confidence interval of differences of $95 \%$ $(p<0.05)$ was chosen to define statistical significance.

\section{Results and discussion}

\subsection{Effect of co-digesting $C$. vulgaris and $\mathrm{PPW}_{\mathrm{dp}}$ with glycerol on $\mathrm{AD}$ performance}

During period III (days 25 to 56), the glycerol feed was maintained at $2 \% \mathrm{v} / \mathrm{v}$ with a high OLR at $1.20 \mathrm{~g} \mathrm{COD} \mathrm{per} \mathrm{L} \mathrm{per} \mathrm{day} \mathrm{for}$ digester C1 (Fig. 1A), whereas the OLR of digester C2 was kept at $0.60 \mathrm{~g}$ COD per L per day (Fig. 2A). The glycerol dosage significantly enhanced volumetric methane production $(F(2,61)=$ $319.67, p<0.001)$. Digester C1 (2\% v/v dosage) had the mean methane production of $0.59 \pm 0.08 \mathrm{~L} \mathrm{CH}_{4}$ per L per d (Fig. $1 \mathrm{~A}$ ), which was significantly higher than $\mathrm{C} 2\left(0.19 \pm 0.02 \mathrm{~L} \mathrm{CH}_{4}\right.$ per L per $\mathrm{d}$; $p<0.001$ ) (Fig. 2A). Methane production of digester C1

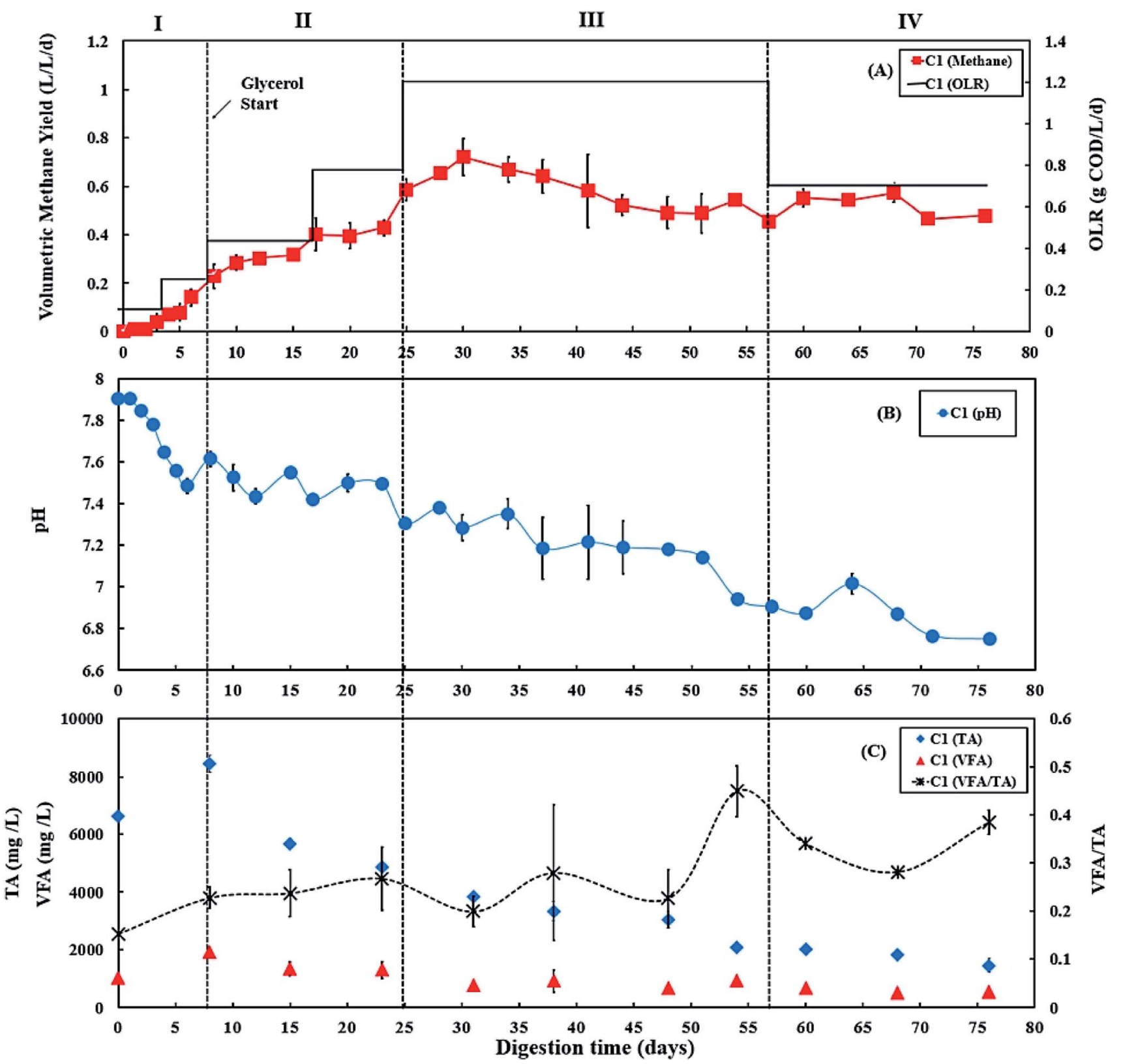

Fig. 1 Variation in (A) volumetric methane yield, (B) pH, and (C) concentrations of total alkalinity (TA), volatile fatty acids (VFA) and ratio of VFA/TA during co-digestion of $C$. vulgaris and potato discarded parts (PPW $\mathrm{dp}$ ) with glycerol (C1). Error bars $=$ mean $\pm \mathrm{SD}, n=2$. 
rapidly increased with glycerol addition, likely due to catabolism of the readily biodegradable soluble COD in glycerol. This agrees with Wohlgemut et al. (2011) in which glycerol doubled methane production with a four times higher OLR when used as a co-substrate with pig manure. ${ }^{32}$

The maximum concentrations of TA and VFA were observed on day 8 for both digesters, after which they decreased continuously (Fig. 1C and 2C). During period III, from days 31 to 48, the average VFA/TA ratio of digester C1 was 0.24 , whereas digester $\mathrm{C} 2$ had a lower ratio of 0.14 . By day 54, VFA concentrations increased slightly to $929 \pm 117 \mathrm{mg} \mathrm{L}^{-1}$ in digester C1 causing the VFA/TA ratio to peak at 0.45 ; Ciotola et al. (2014) and Pontoni et al. (2015) suggested that digesters are overloaded when this ratio exceeded $0.40 .{ }^{47,48} \mathrm{pH}$ values for digester $\mathrm{C} 1$ also showed a declining trend (6.94 \pm 0.01 by day 54) (Fig. 1B), although this remained within the optimum range of 6.8-7.2 for the $\mathrm{AD}$ process. ${ }^{49}$ These results agree with the work of Ciotola et al. (2014), who found that during $\mathrm{AD}$ of dairy manure with a high OLR (1.8 $\mathrm{kg}$ VS per $\mathrm{m}^{3}$ per day), the digester failed at a high VFA/TA ratio of 0.65 , despite $\mathrm{pH}$ remaining at $6.92 .{ }^{47}$ This may have been due to the accumulation of short chain fatty acids leading to a significant reduction of buffering capacity before the $\mathrm{pH}$ dropped, as reported by Ward et al. (2008). ${ }^{\mathbf{9}}$ Glycerol is rapidly consumed by acidogenic bacteria which

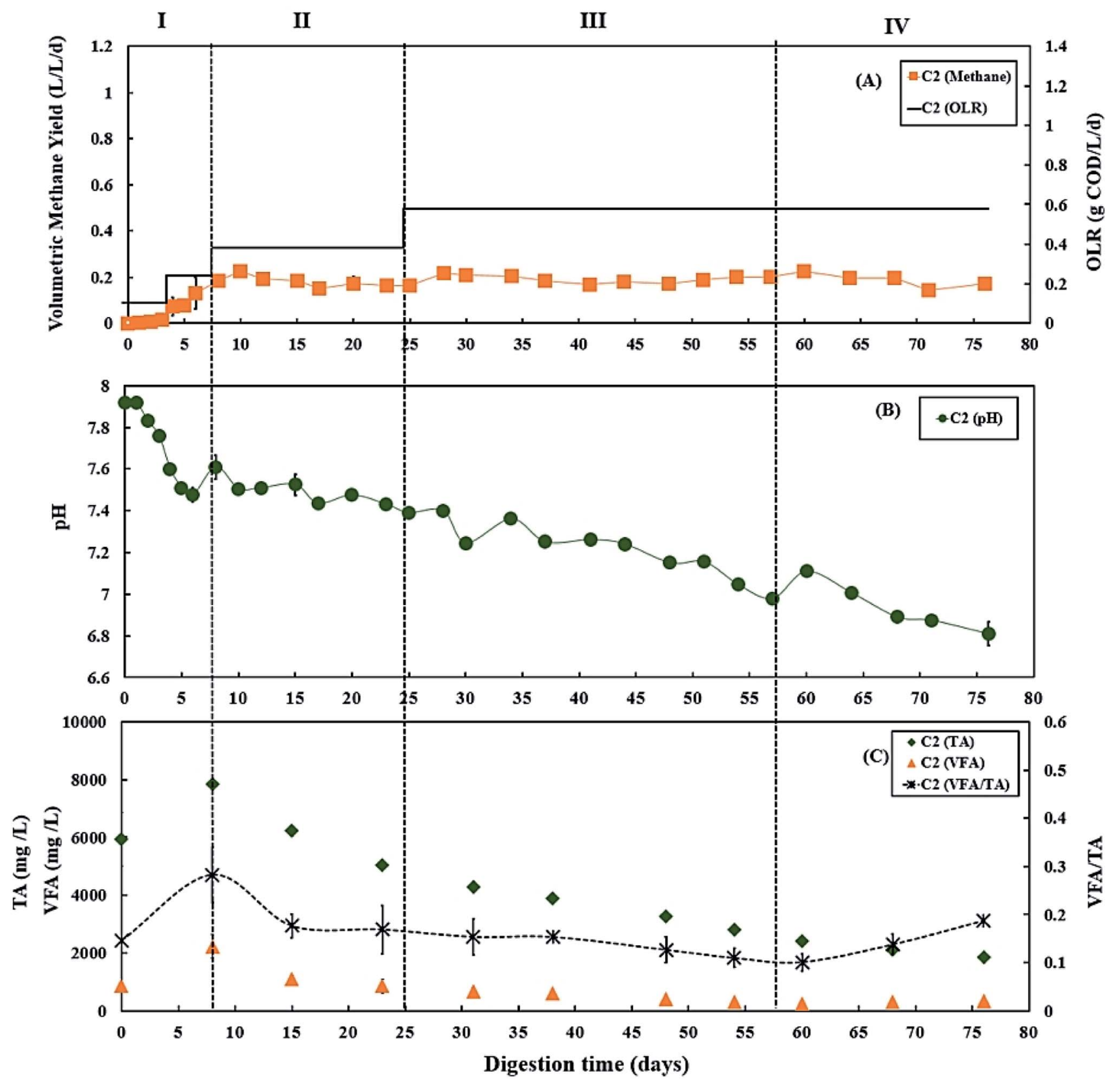

Fig. 2 Variation in (A) volumetric methane yield, (B) $\mathrm{pH}$, and (C) concentrations of total alkalinity (TA), volatile fatty acids (VFA) and ratio of VFA/TA during co-digestion of $C$. vulgaris and potato discarded parts (PPW $\left.{ }_{\mathrm{dp}}\right)$ without glycerol (C2). Error bars $=\operatorname{mean} \pm \mathrm{SD}, n=2$. 
generate large amounts of organic acids $;^{29,30}$ therefore, balanced alkalinity is important for $\mathrm{AD}$ of glycerol. ${ }^{31}$ However, Astals et al. (2012) found that co-digesting pig manure with crude glycerol reduced the alkalinity because glycerol provides negligible alkalinity, resulting in the VFA/TA ratio exceeding $0.60 .^{33}$ Therefore, in their study, the crude glycerol dosage was reduced from 5 to $4 \% \mathrm{w} / \mathrm{w}$ which decreased the VFA/TA ratio to less than 0.4 after two days. In the current study, Fig. $1 \mathrm{C}$ and $2 \mathrm{C}$ show that on day 54, digester $\mathrm{C} 1$ had a lower TA concentration (2062 \pm $\left.18 \mathrm{mg} \mathrm{L}^{-1}\right)$ than digester $\mathrm{C} 2\left(2800 \pm 35 \mathrm{mg} \mathrm{L}^{-1}\right)$. Therefore, on day 57 , the glycerol dosage was reduced to $1 \% \mathrm{v} / \mathrm{v}$, consequently the OLR decreased to $0.70 \mathrm{~g}$ COD per L per day (Fig. 1A).
Consequently, on day 60, the VFA/TA ratio of digester C1 decreased to 0.34 , within the optimum range for stable AD. During period IV (days 57 to 76), the mean volumetric methane yield of $\mathrm{C} 1$ was $0.51 \pm 0.05 \mathrm{~L} \mathrm{CH}_{4}$ per L per d (Fig. 1A) being significantly higher than digester $\mathrm{C} 2\left(0.19 \pm 0.03 \mathrm{~L} \mathrm{CH}_{4}\right.$ per L per $\mathrm{d} ; p<0.001$ ) (Fig. 2A).

\subsection{Effect of co-digesting C. vulgaris and $\mathrm{PPW}_{\mathrm{p}}$ with glycerol on $\mathrm{AD}$ performance}

During period III (from days 25 to 45), when the glycerol feed for digester C3 was increased to $2 \% \mathrm{v} / \mathrm{v}$ with a high OLR at $1.12 \mathrm{~g}$ COD per L per day. Digester C4 was maintained at $0.50 \mathrm{~g}$ COD

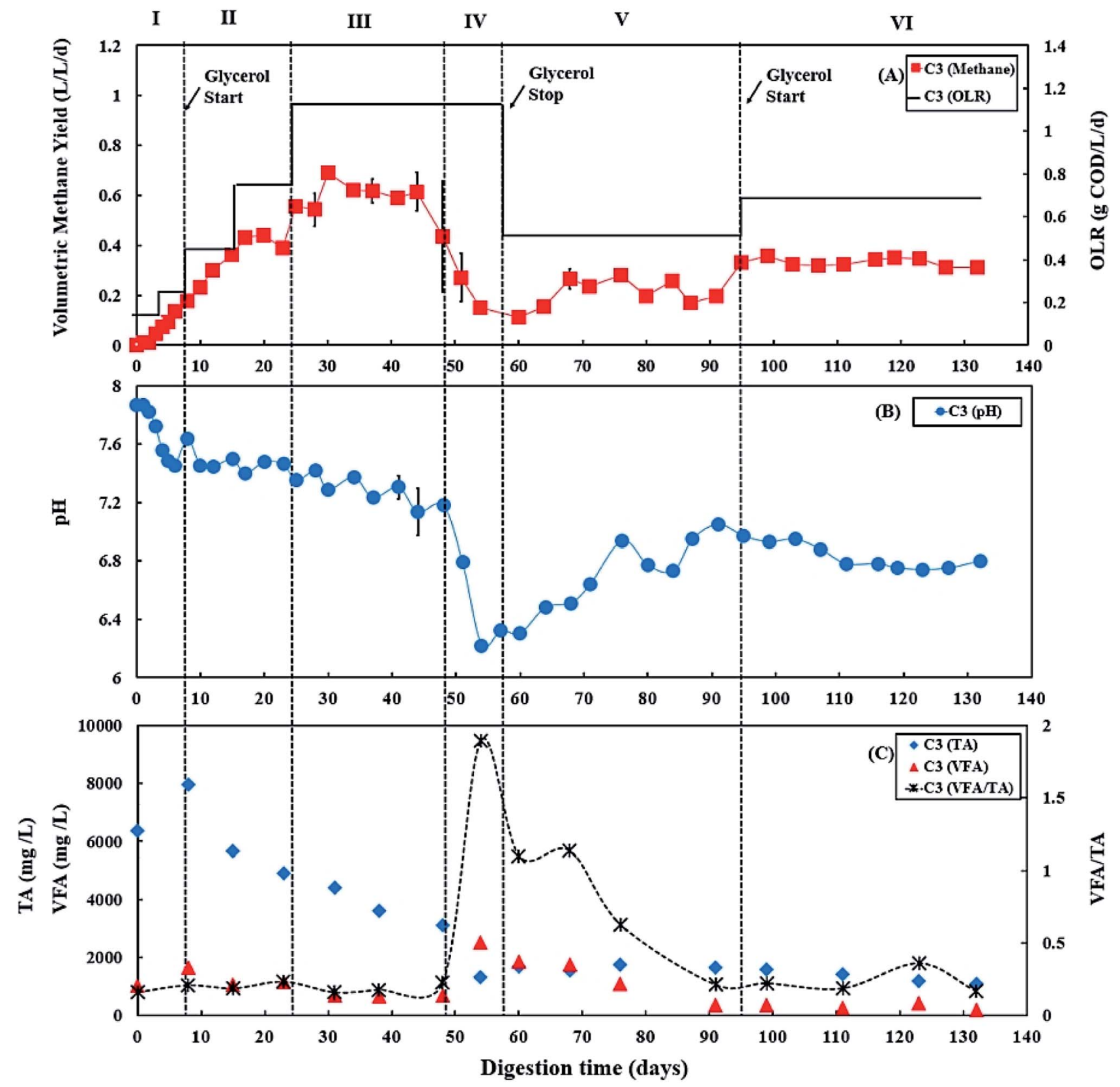

Fig. 3 Variation in (A) volumetric methane yield, (B) pH, and (C) concentrations of total alkalinity (TA), volatile fatty acids (VFA) and ratio of VFA/TA during co-digestion of $C$. vulgaris and potato peel $\left(P P W_{p}\right)$ with glycerol (C3). Error bars $=$ mean $\pm S D, n=2$. 


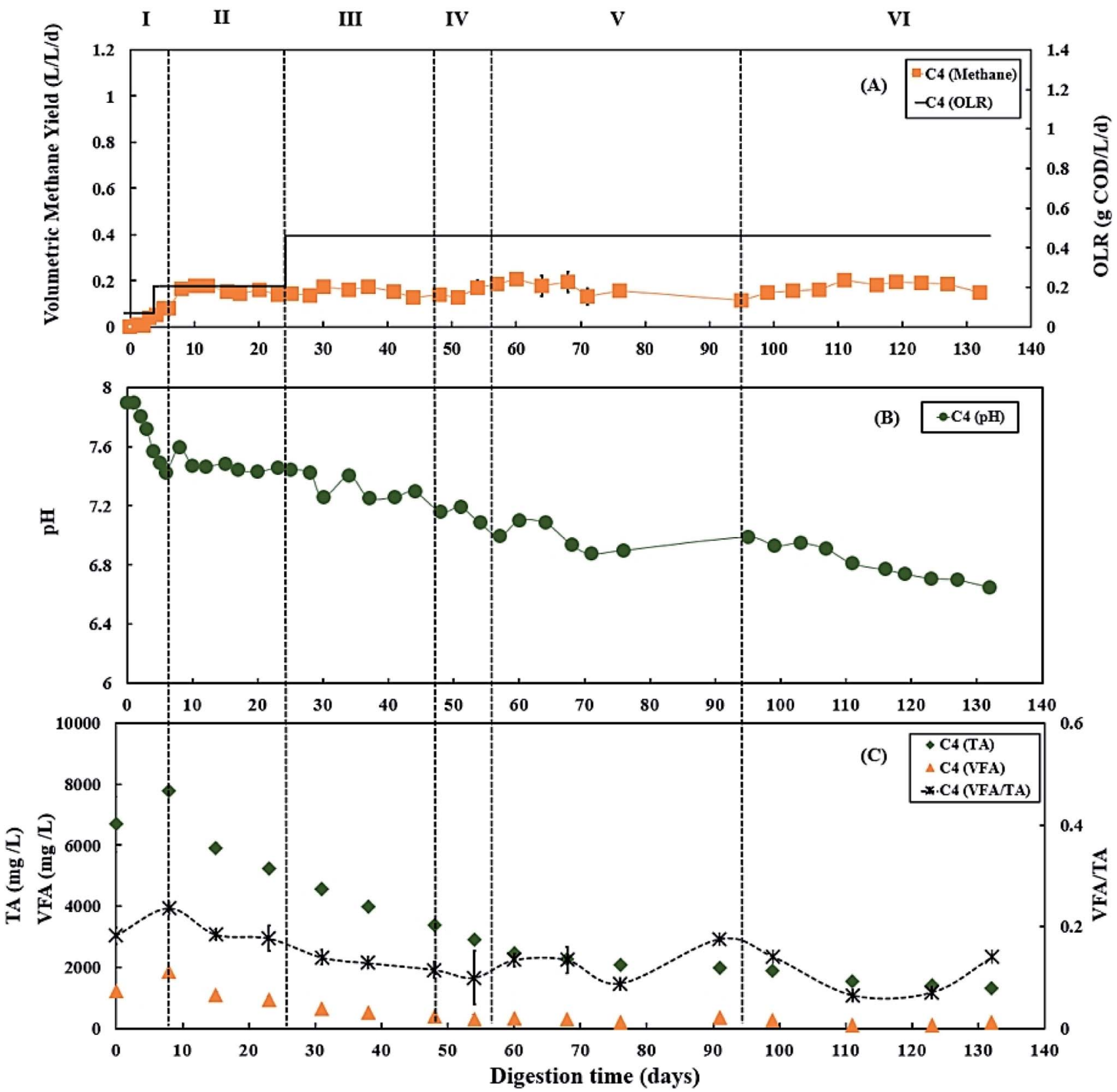

Fig. 4 Variation in (A) volumetric methane yield, (B) pH, and (C) concentrations of total alkalinity (TA), volatile fatty acids (VFA) and ratio of VFA/TA during co-digestion of $C$. vulgaris and potato peel (PPW $)$ without glycerol (C4). Error bars $=$ mean $\pm S D, n=2$.

per L per day of OLR. Fig. 3B and 4B show that there was a slow reduction of $\mathrm{pH}$ in both $\mathrm{C} 3$ and $\mathrm{C} 4$ during period III. The glycerol dosage significantly affected the volumetric methane production $(F(2,65)=916.41, p<0.001)$. During period III, the mean volumetric methane production of $0.60 \pm 0.05 \mathrm{~L} \mathrm{CH}_{4}$ per $\mathrm{L}$ per $\mathrm{d}$ in digester $\mathrm{C}$, which was significantly higher than the level of $0.15 \pm 0.02 \mathrm{~L} \mathrm{CH}_{4}$ per L per d in digester $\mathrm{C} 4(p<$ 0.001 ).

The TA and VFA concentrations of digesters C3 and C4 also peaked after 8 days of operation, then decreased continuously until day 48 (Fig. 3C and 4C). Subsequently, the TA and VFA concentrations continued to decrease in digester $\mathrm{C} 4$, with a relatively stable VFA/TA ratio. However, digester C3 started to accumulate VFA and experienced reduced TA concentrations, resulting in the VFA/TA ratio peaking at 1.89 on day 54 , corresponding with a significant drop in $\mathrm{pH}$ of digester $\mathrm{C} 3$ to 6.22 and decreased methane production. VFAs are crucial intermediate products affecting methane production and AD process stability, and glycerol degradation by acidogenic bacteria produces VFA. Propionic acid degrading microorganisms have lower specific growth rates than acetic acid- or butyric acid consumers that require longer degradation times. ${ }^{50-52}$ Therefore, Nielsen et al. (2007) and Xiao et al. (2015) suggested that propionic acid accumulation could be one of the major 
parameters indicating $\mathrm{AD}$ process instability. ${ }^{53,54}$ The growth rates of both acidogenic bacteria and methanogens are inhibited when propionic acid concentrations exceed $900 \mathrm{mg} \mathrm{L}^{-1}$, leading to reduced methane production..$^{55}$ On day 54 of the current study, the total propionic acid concentration in digester C3 was $1220 \mathrm{mg} \mathrm{L}^{-1}$ (Fig. S2A in ESI $\dagger$ ), which probably explains the reduction in methane yields in digester $\mathrm{C} 3$ at that time.

Lossie and Pütz (2008) suggested that the input of biomass to a digester should be reduced or stopped if the VFA/TA ratio exceeds $0.6{ }^{42}$ Therefore, on day 57 , the feed of glycerol to digester C3 was stopped, with only the baseline feed of $25: 75 \mathrm{C}$. vulgaris : $\mathrm{PPW}_{\mathrm{p}}$ used to recover it during period $\mathrm{V}$. The recovery stage of period $\mathrm{V}$ lasted for 37 days (from days 57 to 94), and the OLR of digester $\mathrm{C} 3$ was maintained at $0.50 \mathrm{~g}$ COD per L per day. During this recovery stage, $\mathrm{pH}$, methane production and TA concentrations in digester C3 exhibited increasing trends (Fig. 3), while VFAs, especially propionic acid, decreased continuously, reducing the VFA/TA ratio from 1.89 to 0.21 (Fig. 3C). Lossie and Pütz (2008) also suggested that biomass loading should be increased slowly when the VFA/TA ratio ranges from 0.2 to $0.3 .^{42}$ Therefore, after recovery, during period VI, glycerol feeding was restarted at $1 \% \mathrm{v} / \mathrm{v}$ to digester $\mathrm{C} 3$ on day 95, and the OLR was increased to $0.67 \mathrm{~g}$ COD per L per day (Fig. 3A). Period VI lasted 37 days (from days 95 to 132), the mean volumetric methane production of $0.33 \pm 0.02 \mathrm{~L} \mathrm{CH}_{4}$ per $\mathrm{L}$ per $\mathrm{d}$ in digester $\mathrm{C} 3$, which was significantly higher than $0.17 \pm 0.03 \mathrm{~L} \mathrm{CH}_{4}$ per L per d produced by digester $\mathrm{C} 4(p<$ $0.001)$.

\subsection{Overall performance during co-digestion}

The glycerol dosage level is a key factor affecting final methane production when using glycerol as a co-substrate because of its high COD concentration. Rapidly introducing high glycerol dosage would suddenly increase the OLR, and reduce digester performance by creating a "shock load" as described by Wohlgemut et al. (2011). ${ }^{32}$ In their study, the volumetric biogas/ methane production stopped after 12 days because of VFA accumulation $\left(>10000 \mathrm{mg} \mathrm{L}^{-1}\right)$ when pig manure was codigested with $4 \% \mathrm{v} / \mathrm{v}$ glycerol. Similarly, co-digestion with $2 \%$ v/v glycerol also accumulated VFAs (>7000 $\left.\mathrm{mg} \mathrm{L}^{-1}\right)$ after 25 days. During period II in the current study, a slow and stepwise increase in glycerol dosage from 1 to $2 \% \mathrm{v} / \mathrm{v}$ was implemented successfully without creating any organic shock load.

In the current study, the $\mathrm{C} / \mathrm{N}$ ratios in the mixtures of $25 \% C$. vulgaris with $75 \% \mathrm{PPW}_{\mathrm{dp}}$ or $\mathrm{PPW}_{\mathrm{p}}$ were 22.8 and 19.9 , respectively, both of which are within the optimum range for $\mathrm{AD}$ process..$^{18}$ Co-digestion of C. vulgaris and PPW at this ratio could achieve stable digestion process as shown in Fig. 2 and 4 . Although $\mathrm{PPW}_{\mathrm{dp}}$ and $\mathrm{PPW}_{\mathrm{p}}$ are both promising feedstocks for stable microalgae co-digestion, the addition of small amounts $(1-2 \% \mathrm{v} / \mathrm{v})$ of glycerol significantly enhanced volumetric methane yield $\left(\mathrm{PPW}_{\mathrm{dp}}: F(2,61)=319.67, p<0.001\right.$ PPW $_{\mathrm{p}}$ : $F(2,65)=916.41, p<0.001)$. The addition of glycerol also significantly enhanced specific methane yield ( $\mathrm{PPW}_{\mathrm{dp}}: F(2,61)=$ $213.67, p<0.001 ;$ PPW $\left._{\mathrm{p}}: F(2,65)=207.72, p<0.001\right)$. Although the higher glycerol dose led to enhanced volumetric methane production, the highest specific methane yield was achieved with the lower dose. When mixtures of $C$. vulgaris : $\mathrm{PPW}_{\mathrm{dp}}$ codigesting with $1 \% \mathrm{v} / \mathrm{v}$ glycerol, the mean specific methane yield of $0.73 \pm 0.07 \mathrm{~L} \mathrm{CH}_{4}$ per $\mathrm{g} \mathrm{COD}_{\text {added }}$ (based on total COD) was significantly higher than with $0 \% \mathrm{v} / \mathrm{v}$ dosage (mean of 0.30 $\pm 0.04 \mathrm{~L} \mathrm{CH}_{4}$ per g COD added, $\left.p<0.001\right)$ and $2 \% \mathrm{v} / \mathrm{v}$ dosage (mean of $0.49 \pm 0.07 \mathrm{~L} \mathrm{CH}_{4}$ per $\mathrm{g} \mathrm{COD}$ added, $p<0.001$ ). When mixtures of C. vulgaris : $\mathrm{PPW}_{\mathrm{p}}$ co-digesting with $1 \% \mathrm{v} / \mathrm{v}$ glycerol, the specific methane yield (mean of $0.55 \pm 0.03 \mathrm{~L} \mathrm{CH}_{4}$ per $\mathrm{g}$ $\mathrm{COD}_{\text {added }}$ ) was significantly higher than with $0 \% \mathrm{v} / \mathrm{v}$ dosage (mean of $0.33 \pm 0.05 \mathrm{~L} \mathrm{CH}_{4}$ per $\mathrm{g} \mathrm{COD}$ added,$p<0.001$ ). The mean specific methane yield of $0.54 \pm 0.04 \mathrm{~L} \mathrm{CH}_{4}$ per $\mathrm{g} \mathrm{COD}_{\text {added }}$ was observed when mixtures of $C$. vulgaris : $\mathrm{PPW}_{\mathrm{p}}$ co-digesting with $2 \% \mathrm{v} / \mathrm{v}$ glycerol. There was no significant difference between the specific methane yield at the $2 \%$ and $1 \% \mathrm{v} / \mathrm{v}$ dosage $(p=0.687)$. Moreover, the addition of $2 \% \mathrm{v} / \mathrm{v}$ glycerol was more likely to accumulate VFA, resulting in high VFA/TA ratios, leading to a potentially unbalanced system. Consequently, $1 \% \mathrm{v} / \mathrm{v}$ glycerol appears to be the better dosage when applied to $25: 75$ codigestion mixture of $C$. vulgaris/PPW. This agrees with Fountoulakis et al. (2010) and Panpong et al. (2014) who applied 1\% $\mathrm{v} / \mathrm{v}$ glycerol during co-digestion with sewage sludge or canned seafood wastewater, doubling the volumetric methane production and specific methane yield. ${ }^{56,57}$ However, their systems also showed signs of organic overloading because of increased VFA concentrations and decreased $\mathrm{pH}$ when the dosage exceeded $1 \% \mathrm{v} / \mathrm{v}$.

In the current study, when adding glycerol to the mixtures of microalgae : PPW, the experimental specific methane yield exceeded the theoretical value $\left(0.35 \mathrm{~L} \mathrm{CH}_{4}\right.$ per $\mathrm{g}$ COD under STP). Glycerol is a readily degradable substrate, and Nguyen (2014) found that digestion of glycerol achieved the specific methane yield of $0.75 \mathrm{~L} \mathrm{CH}_{4}$ per $\mathrm{g}$ COD, which is higher than the theoretical value. ${ }^{58}$ Similar observations were reported by Fountoulakis et al. (2010) who investigated the effect of codigesting glycerol and sewage sludge, finding that the addition of glycerol could supply the extra organic carbon that enhanced the growth of active biomass in terms of increased VS values, and consequently the observed methane production exceeded the theoretical yield. ${ }^{56}$ Ma et al. (2008) also demonstrated that the addition of glycerol to potato processing wastewater had a positive effect on the growth of the active biomass which increased the amount of VS of $3 \mathrm{~g}$ VS L ${ }^{-1}$ after glycerol addition. ${ }^{59}$ In the current study, at the end of period III, the VS values increased when adding $2 \% \mathrm{v} / \mathrm{v}$ glycerol (C1 and C3), which were significantly higher than the digesters (C2 and C4) without glycerol $(t(6)=-7.799, p<0.001)$ (Tables S1 and S2 in ESI†). Similarly, the VS values in digesters C1 and C3 were significantly higher than $\mathrm{C} 2$ and $\mathrm{C} 4$ at the end of period IV and period VI $(t(6)=-3.243, p=0.018)$ (Tables S1 and S2 $\dagger$ ). In the current study, the enhanced methane yield beyond theoretical values might be because the active biomass (increased VS values) was enhanced by adding glycerol. Apart from this, the potential biodegradable COD has been accumulated in the digester for some time could be another possible reason for the observed high specific methane yield. Specifically, in the current study, the seed inoculum was collected from a manure- 
based anaerobic digester, which normally requires high OLR (3 g COD per L per day) to degrade it. ${ }^{60}$ However, the low OLR used in the current study results in less biomass is required to degrade the daily feed, therefore the extra biomass in the inoculum would be degraded and produce extra methane production. Moreover, in the current study, the digesters were fed slowly with glycerol at low dosage during period II, and then were fed every two days. Consequently, the residual biomass in
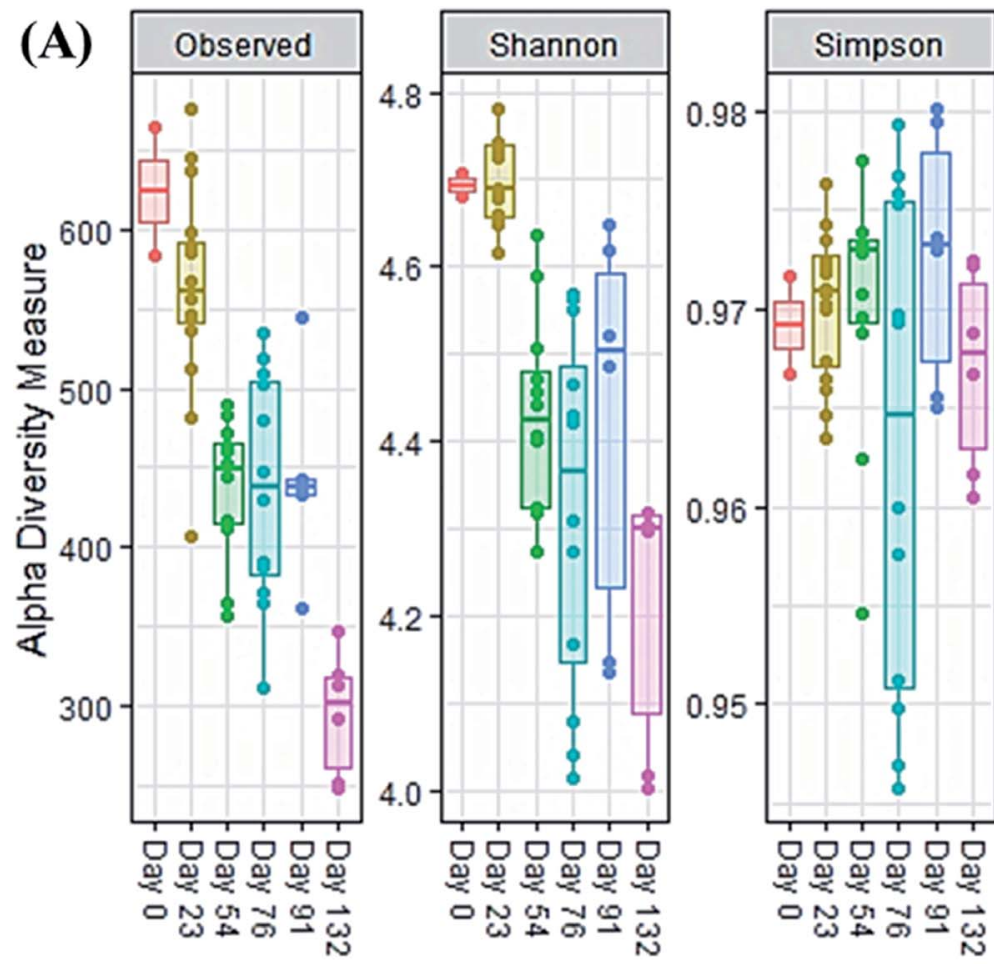

Time
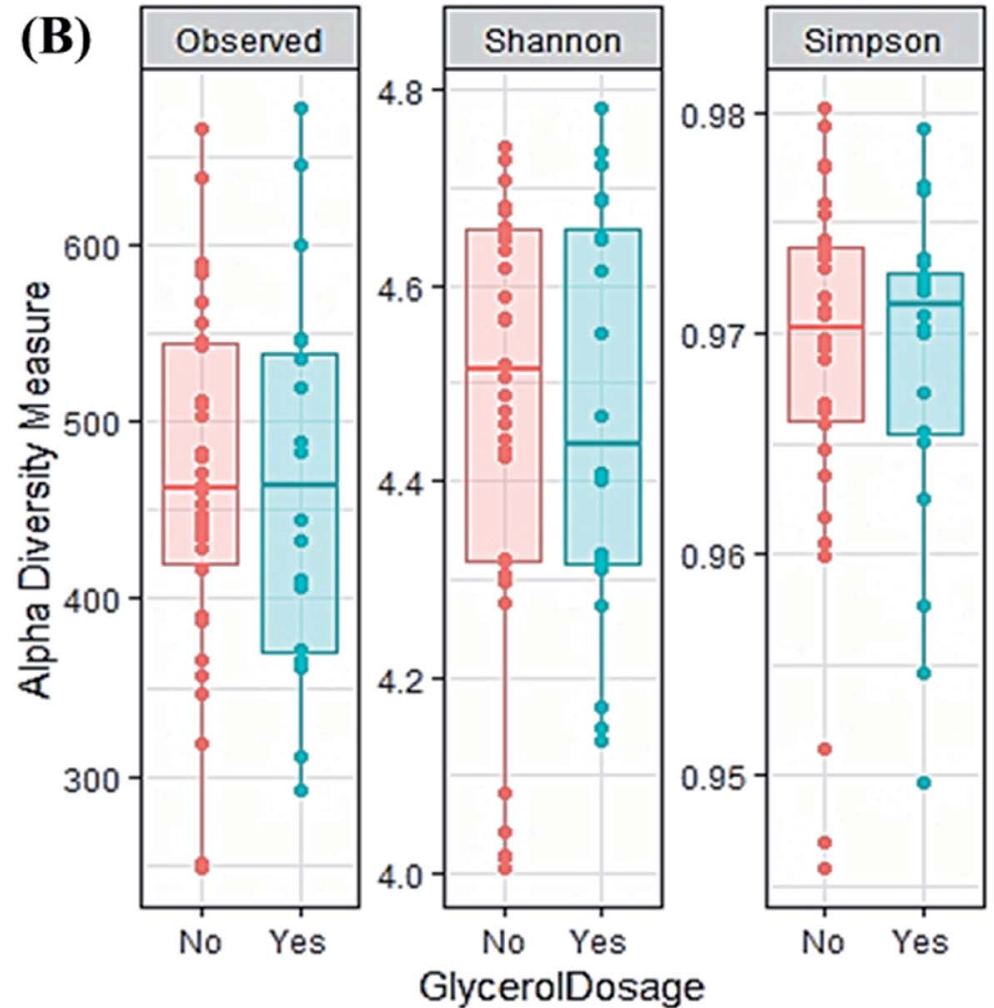

Time

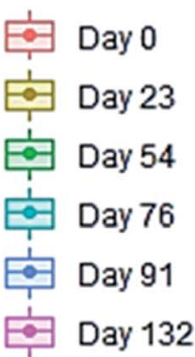

\section{GlycerolDosage}

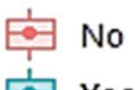

Fig. 5 Alpha diversity indices of all samples during the co-digestion process: (A) time effect; (B) feedstock effect (with or without glycerol). 
the digester may gradually adapt to the previously nondegradable material, which may start to degrade it and produce more methane. Similar observations were reported by Sayed et al. (1984), in their study, the observed percentage of COD conversion to methane higher than 100\% (111-121\%) when the slaughterhouse waste was fed into the anaerobic reactor slowly and intermittently. ${ }^{61}$ The current study has yielded important findings that glycerol as an additional feedstock could improve methane yields when co-digesting with microalgae and PPW. However, in order to minimise these influences, it suggests that the digesters should operate some time to deplete the internal source of methane. Therefore, validation of the result is required for the future study, such as prolong the start-up time of the anaerobic digester, to develop a clear understanding the performance of glycerol as co-substrate for future microalgae biorefineries.

FAN is regarded as the active component leading to ammonia inhibition in AD processes, ${ }^{62}$ and microalgae biomass is characterised by having high protein content which can lead to high ammonia concentrations and inhibition when used as a mono-digestion feedstock. In the current study, the FAN concentrations of all digesters were less than $10 \mathrm{mg} \mathrm{L}^{-1}$, lower than previously reported methanogenic toxicity levels of 80$150 \mathrm{mg} \mathrm{L}{ }^{-1} .^{15,63}$ Therefore, the current study demonstrated that co-digestion of C. vulgaris and PPW, both with and without glycerol, helps avoid the development of ammonia toxicity.

\subsection{Microbial characteristics}

3.4.1 Comparison of community diversity and similarity. A comparison of $\alpha$-diversity was used to determine differences in microbial community richness and evenness using observed OTU numbers, Shannon's and Simpson's indices. ${ }^{64}$ Operation time significantly reduced community richness $(p<0.001)$ (Fig. 5A). For example, OTU diversity was significantly higher in the inoculum (day 0) compared with day $54(p=0.002)$, day 76 ( $p$ $=0.002)$ and day $132(p<0.001)$. Operation time also significantly reduced Shannon diversity $(p<0.001)$ (Fig. 5A). The community on day 0 was more diverse than other sampling dates, but only significantly higher than day $76(p=0.02)$ and day $132(p=0.002)$. However, Simpson's index showed no statistical difference among the operation time $(p=0.097)$. Fig. 5A show that a decrease in alpha diversity was observed from days 0 to 76, and it increased again from days 76 to 91 (during the recovery phase). This agrees with De Vrieze et al. (2017) who found microbial alpha diversity was decreased during the disturbance period, but it increased again during the stabilisation period of the AD process. ${ }^{65}$ Fig. $5 \mathrm{~B}$ shows that there was no significant effect of glycerol addition on any of the alpha diversity measures.

The evolution in microbial community dynamics (beta diversity) over the operation time and with glycerol addition was analysed via principal coordinate analysis (PCoA) of the BrayCurtis distance measure (Fig. 6). Time had a significant effect on community development ( $p=0.001)$, with distinct clustering identifiable for each sampling date; this is unsurprising given the need for the manure-adapted seed inoculum to respond to a markedly different feedstock employed in this study. Days 76 and 91 had substantial overlap (during the recovery phase), the community composition of these two sampling dates was not significantly different $(p=1.000)$. Moreover, the community composition between day 91 and day 132 was not significant ( $p$

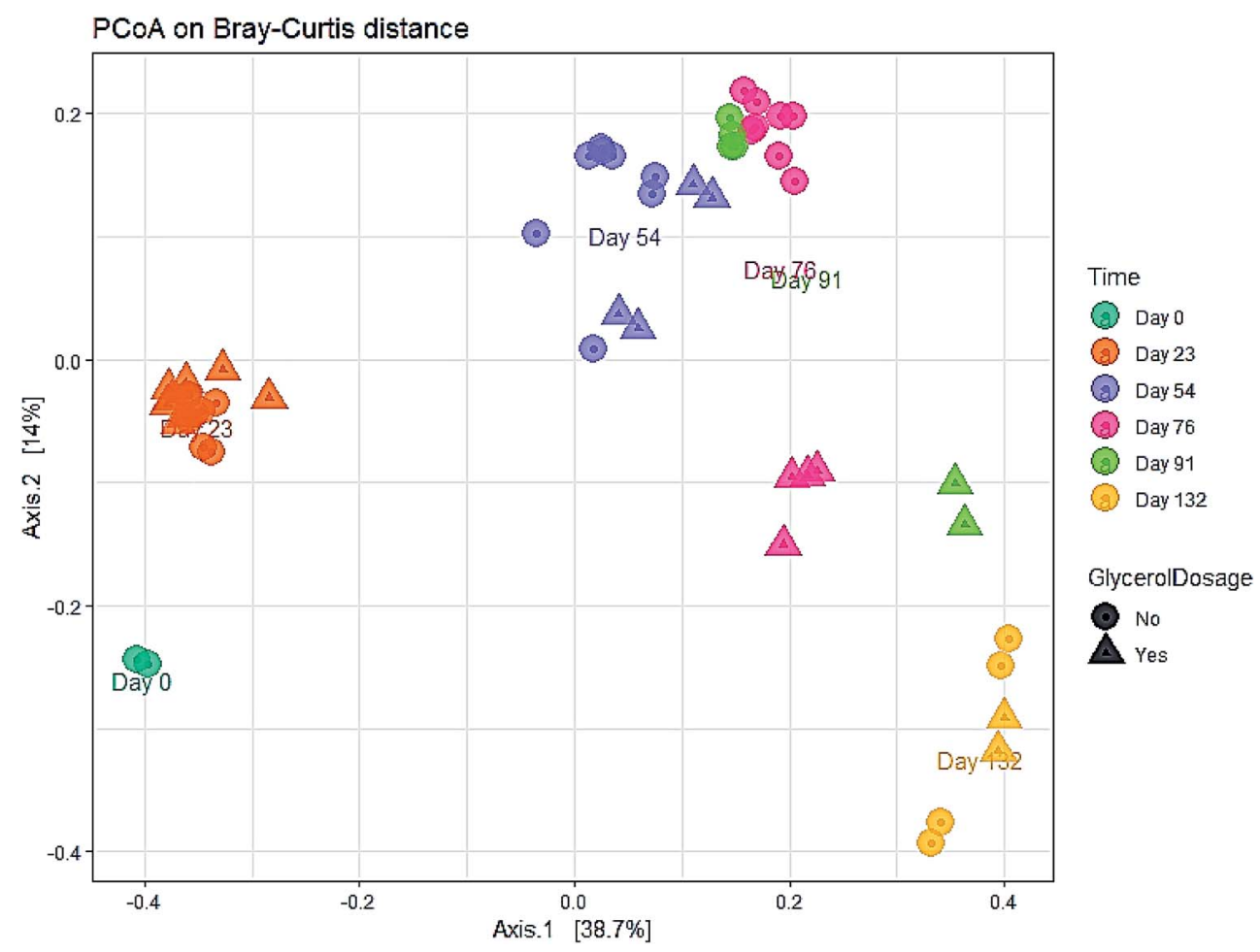

Fig. 6 Principal coordinates plot (PCoA) of the microbial community during the co-digestion process based on Bray-Curtis distance matrix. 

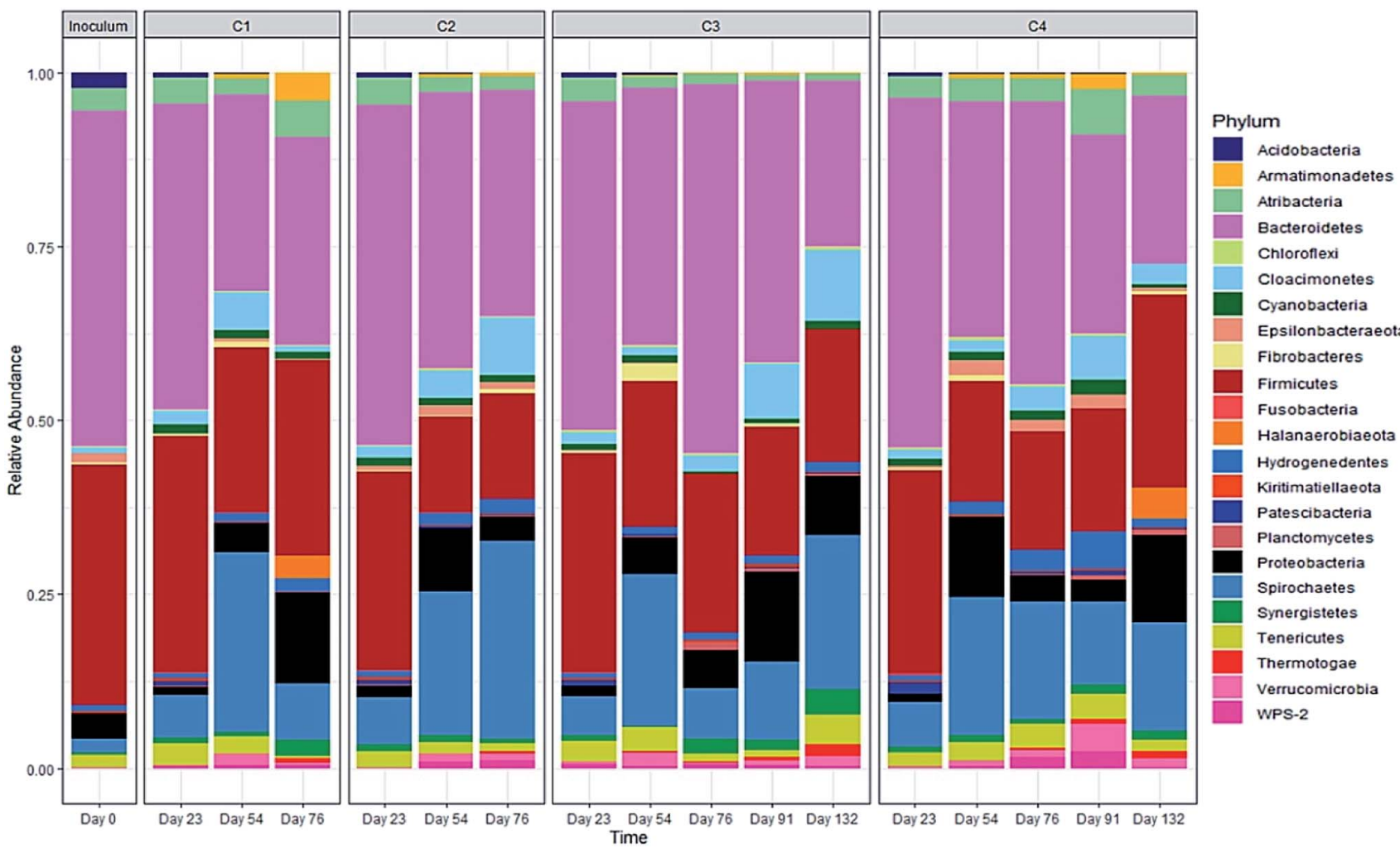

Fig. 7 Relative abundance of the bacterial community at the phylum level ( $>2 \%$ of total sequence).

$=0.06)$. Continued methane production under sub-optimal operating conditions highlights the functional resilience of the communities, even during the recovery phase.

A significant difference in community composition was also observed with glycerol addition $(p=0.024)$. Glycerol amended and unamended treatments grouped within distinct clusters, but with substantial overlap; likely due to switching glycerol feed rates in response to digester instability.

3.4.2 Microbial community composition. Fig. 7 shows the relative abundance of bacterial phyla in seed inoculum and other AD digesters. Bacteroidetes (48\%) and Firmicutes (35\%) were the two dominant phyla in the seed inoculum. The bacteria community was mainly dominated by Bacteroidetes, Firmicutes and Spirochaetes during the co-digestion process. Bacteroidetes abundance fluctuated somewhat in $\mathrm{C} 3$ and $\mathrm{C} 4$, but an overall decreasing trend in all treatments. Firmicutes abundance also exhibited a decreasing trend, at the end of digestion, a higher abundance of Firmicutes was observed in C1 and C4 (both at 28\%). Spirochaetes abundance increased in all treatments from days 23 to 54, and then exhibited the decreasing trend in $\mathrm{C} 1$ and $\mathrm{C} 4$ while a slightly increased abundance was observed in C2 (from 21 to 28\%). After the recovery stage, glycerol was back to add to digester C3 (from days 91 to 132), and Spirochaetes abundance showed an increasing trend (from 11 to $22 \%$ ). In the current study, although the relative abundances of these three dominant phyla fluctuated somewhat in all AD conditions, the glycerol dosage had no significant effect on the relative abundances of Bacteroidetes $(p=0.902)$,
Firmicutes ( $p=0.348)$ and Spirochaetes $(p=0.649)$. Bacteria are responsible for the first three steps of $\mathrm{AD}$ process, and in comparison with methanogens, bacteria are normally not severely affected by the changes of operational conditions and/ or the presentence of inhibitory substances, and consequently they may not pose severe problems. ${ }^{66,67}$

The relative abundance of the methanogens are presented in Fig. 8 and 9. Among the methanogens, Methanosaeta had the highest relative abundance in the seed inoculum and remained dominant up to day 54. Methanosaeta abundance fluctuated somewhat in $\mathrm{C} 2$ but an overall decreasing trend was evident over the extended sampling periods for digesters C3 and C4. Methanosaeta, as a specialist acetate degrader, is expected to be favored in low acetic acid environments $\left(<100 \mathrm{mg} \mathrm{L}^{-1}\right) .^{68,69} \mathrm{It}$ should be noted that the genus name Methanosaeta apply to the same taxon as Methanothrix. ${ }^{70}$ However, in the current study, to prevent confusion we use the established name (Methanosaeta) as it is generally used in very recent studies.,71 From days 23 to 54 , the total VFA concentrations of digesters C1, C2 and C4 decreased steadily, with acetic acid concentrations remaining below $100 \mathrm{mg} \mathrm{L}^{-1}$ (Fig. S1 and S2 $\uparrow$ ); acetic acid concentration correlating negatively with Methanosaeta abundance $\left(r_{\mathrm{s}}(34)=\right.$ $-0.395, p=0.021$ ). Digester C3 experienced performance inhibition by day 54 through VFA accumulation and low $\mathrm{pH}$ (Fig. 3A), and had to be recovered. During recovery, the high acetic acid concentration was effectively degraded, supporting a shift in dominance to Methanosarcina (up to $66 \%$ relative abundance). Methanosarcina is a robust acetoclastic 


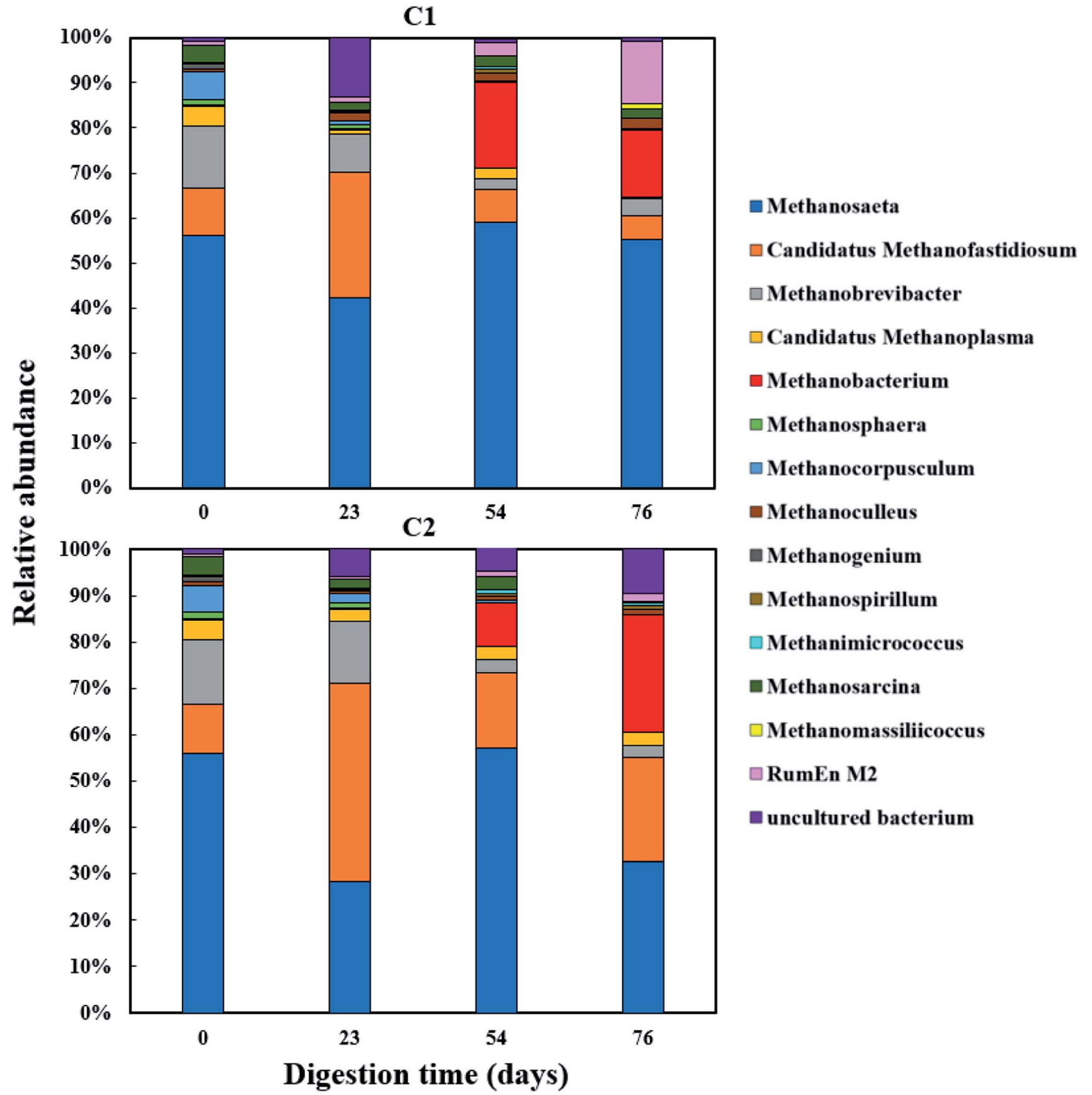

Fig. 8 Relative abundance of methanogenic archaea (genus level) during co-digestion of C. vulgaris and potato discarded parts (PPW dp ) with (C1) or without (C2) glycerol addition.

methanogen that can utilize acetate, $\mathrm{CO}_{2}$, methyl-group containing compounds or $\mathrm{H}_{2}$ as substrate. ${ }^{68}$ It survives at $\mathrm{pH} 5-8$ and is often associated with deteriorating digester performance. ${ }^{69,72}$ In C3, Methanosarcina abundance and methane production were negatively correlated $\left(r_{\mathrm{s}}(34)=-0.487, p=\right.$ $0.004)$, with abundance exhibiting a decreasing trend from day 91 to 132 . The relative abundance of Methanoculleus increased from 6 to $41 \%$ over this period, becoming the dominant genus in digester $\mathrm{C} 3$ at the end of the digestion process. Furthermore, Methanosaeta dominance was lost in digester C4 by day 132, yielding to Methanoculleus and the $\mathrm{H}_{2}$-dependent methylotroph Methanomassiliicoccales and the archaeon RumEn M2 (Fig. 9). ${ }^{73}$ Methanoculleus is a hydrogenotrophic methanogen that grows favourably at low acetate and hydrogen concentrations that were prevalent during the pseudo of period VI. ${ }^{74}$ De Vrieze et al. (2012) reported that a robust methanogenic process can be established based on syntrophic acetate oxidation coupled with hydrogenotrophic methanogenesis by Methanosarcina under elevated OLR conditions. ${ }^{72}$ Therefore, during period VI the high methane production achieved by digester C3 was probably 


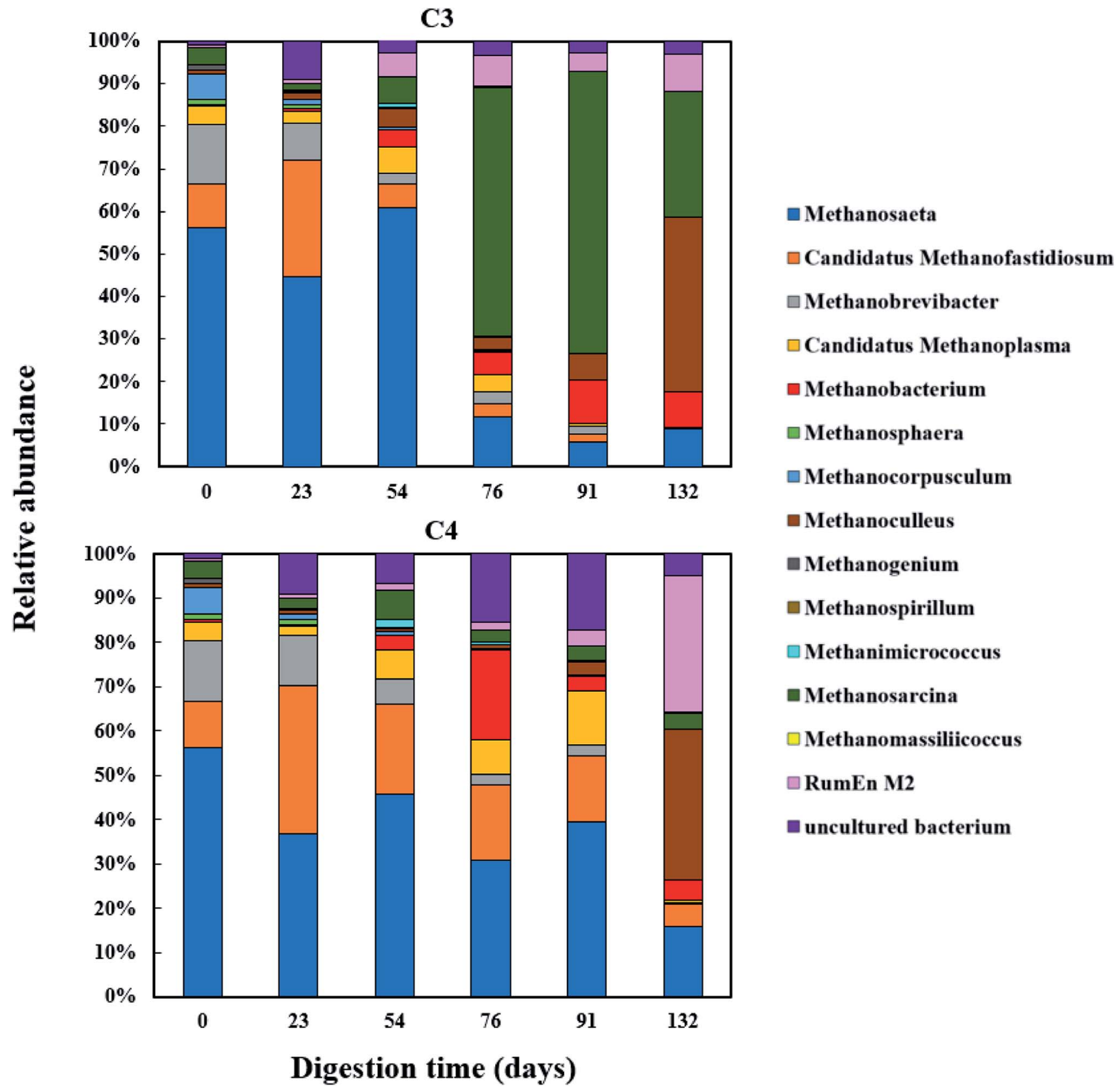

Fig. 9 Relative abundance of methanogenic archaea (genus level) during co-digestion of $C$. vulgaris and potato peel (PPWp) with (C3) or without (C4) glycerol addition.

a result of interactions between Methanosarcina and Methanoculleus. Other notable community features included the maintenance of high relative abundances of the methylreducing syntroph, Candidatus Methanofastidiosum (formerly WSA2 $)^{75}$ in digesters without glycerol (C2 and $\left.\mathrm{C} 4\right)$, and the strong growth of the hydrogentrophic methanogen Methanobacterium, which can utilize $\mathrm{H}_{2}$ (formate) to produce methane, in digesters $\mathrm{C} 1$ and $\mathrm{C} 2$ from day 54 .

\subsection{Technical and economic implications from co-digestion with glycerol}

The current study shows glycerol to be a promising co-substrate for the co-digestion of microalgae and PPW to further enhance methane production. Previously, it has been discussed that the OLRs may potentially be increased when co-digesting microalgae with PPW. ${ }^{22}$ In the current study, glycerol supplementation allowed the operating OLRs to be further increased. Therefore, if the co-digestion of microalgae and PPW can be applied in large-scale $\mathrm{AD}$, utilisation of glycerol as an additional feedstock may potentially further reduce the digester's size and capital costs.

Moreover, methane production was significantly enhanced when conducting co-digestion with glycerol at an optimum dosage of $1 \% \mathrm{v} / \mathrm{v}$. When using microalgae as a substrate for biofuel production, one factor affecting financial viability is the transportation of the biomass to the operational site. ${ }^{76}$ In 
addition, feedstock availability is another important consideration when operating an AD plant. Therefore, when considering microalgae $\mathrm{AD}$ as part of a biorefinery concept, particularly where biodiesel production is one step in the value chain, glycerol will be produced on site thereby providing a readily available co-digestion feedstock and reducing the transportation costs. Another area which needs further consideration is the large amount of glycerol produced from biodiesel production that may require additional treatment, and this may potentially increase the cost of on-site waste management. ${ }^{76}$ Therefore, from an economic viewpoint, co-digestion with glycerol may be a technique that could be used to improve the overall efficiency of the $\mathrm{AD}$ process and the economics of the biorefinery plant. However, the utilisation of glycerol as a cosubstrate requires a further economic viability analysis due to its high value as a chemical feedstock. ${ }^{77}$

To date, information concerning continuous digesters fed with microalgae biomass is still very limited compared to BMP tests. During the current work, the semi-continuous anaerobic tests focused on an evaluation of the potential benefits of using carbon-rich waste materials as co-digestion substrates. Since operating parameters such as OLR, HRT and mixing conditions are known to affect the performance of the $\mathrm{AD}$ process and influence methane production, it is therefore proposed that future work should investigate the effect of OLR and/or HRT as well as mixing conditions (e.g. continuous mixing) on the codigestion of microalgae with potato processing waste and glycerol. The current study is focusing on studying the effect of glycerol dosage level on methane production when co-digestion with microalgae and PPW. The characteristics of glycerol may also have the potential effect on the co-digestion process, such as its $\mathrm{C} / \mathrm{N}$ ratio and purity. Therefore, future research should be conducted to determine whether the $\mathrm{C} / \mathrm{N}$ ratio and/or purity of glycerol have additional effect over the current study.

\section{Conclusion}

The feasibility of using glycerol as an additional co-substrate for the co-digestion of microalgae and PPW was evaluated in semicontinuous digester studies. When co-digesting with mixtures of C. vulgaris : $\mathrm{PPW}_{\mathrm{dp}}$, the highest specific methane was achieved by $1 \% \mathrm{v} / \mathrm{v}$ glycerol dosage, which was significantly higher than $2 \%$ and $0 \% \mathrm{v} / \mathrm{v}$ dosage. When co-digesting with mixtures of C. vulgaris : $\mathrm{PPW}_{\mathrm{p}}$, the highest specific methane yields was also achieved by $1 \% \mathrm{v} / \mathrm{v}$ glycerol dosage, which was significantly higher than $0 \% \mathrm{v} / \mathrm{v}$ dosage. However, there was no significant difference between 1 and $2 \% \mathrm{v} / \mathrm{v}$ dosage. Moreover, the $2 \% \mathrm{v} / \mathrm{v}$ dosage promoted the accumulation of VFA leading to an unstable process and requiring one treatment to be recovered. The microbial communities diverged markedly over operational time, and to a lesser extent in response to glycerol addition. The acetoclast Methanosaeta was abundant in all treatments but was replaced by Methanosarcina in the $\mathrm{PPW}_{\mathrm{dp}}$ with glycerol treatment due to VFA accumulation. Overall, this study demonstrate that the performance of microalgae co-digestion is substantially improved by the addition of glycerol as an additional cosubstrate, suggesting that $1 \% \mathrm{v} / \mathrm{v}$ could be the optimal dosage when co-digesting with mixtures of $C$. vulgaris : PPW to enhance methane production without organic overloading.

\section{Conflicts of interest}

There are no conflicts to declare.

\section{Acknowledgements}

This study is part of a PhD at Newcastle University. The authors also gratefully acknowledge the on-going support of the UK's Engineering and Physical Sciences Research Council (EPSRC) through the following funding awards: LC TRANSFORMS (Low Carbon Transitions of Fleet Operations in Metropolitan Sites EP/N010612/1); and CESI (Centre for Energy Systems Integration EP/P001173/1).

\section{References}

1 GOV.UK, The Grand Challenges, 2017, cited 2020 May, available from, https:/www.gov.uk/government/ publications/industrial-strategy-the-grand-challenges/ industrial-strategy-the-grand-challenges.

2 O. Ellabban, H. Abu-Rub and F. Blaabjerg, Renewable energy resources: Current status, future prospects and their enabling technology, Renewable Sustainable Energy Rev., 2014, 39, 748-764.

3 K. W. Chew, J. Y. Yap, P. L. Show, N. H. Suan, J. C. Juan, T. C. Ling, D.-J. Lee and J.-S. Chang, Microalgae biorefinery: high value products perspectives, Bioresour. Technol., 2017, 229, 53-62.

4 Y. Zhang, G. S. Caldwell and P. J. Sallis, Semi-continuous anaerobic co-digestion of marine microalgae with potato processing waste for methane production, J. Environ. Chem. Eng., 2019, 7(1), 102917.

5 S. L. Lim, W. L. Chu and S. M. Phang, Use of Chlorella vulgaris for bioremediation of textile wastewater, Bioresour. Technol., 2010, 101(19), 7314-7322.

6 F. Delrue, P. A. Setier, C. Sahut, L. Cournac, A. Roubaud, G. Peltier and A. K. Froment, An economic, sustainability, and energetic model of biodiesel production from microalgae, Bioresour. Technol., 2012, 111, 191-200.

7 N. Préat, S. E. Taelman, S. De Meester, F. Allais and J. Dewulf, Identification of microalgae biorefinery scenarios and development of mass and energy balance flowsheets, Algal Res., 2020, 45, 101737.

8 R. Craggs, J. Park, S. Heubeck and D. Sutherland, High rate algal pond systems for low-energy wastewater treatment, nutrient recovery and energy production, N. Z. J. Bot., 2014, 52(1), 60-73.

9 A. F. Miranda, N. Ramkumar, C. Andriotis, T. Höltkemeier, A. Yasmin, S. Rochfort, D. Wlodkowic, P. Morrison, F. Roddick and G. Spangenberg, Applications of microalgal biofilms for wastewater treatment and bioenergy production, Biotechnol. Biofuels, 2017, 10(1), 120.

10 A. Pfluger, J. Coontz, V. Zhiteneva, T. Gulliver, L. Cherry, L. Cavanaugh and L. Figueroa, Anaerobic digestion and 
biogas beneficial use at municipal wastewater treatment facilities in Colorado: a case study examining barriers to widespread implementation, J. Cleaner Prod., 2019, 206, 97-107.

11 B. Sialve, N. Bernet and O. Bernard, Anaerobic digestion of microalgae as a necessary step to make microalgal biodiesel sustainable, Biotechnol. Adv., 2009, 27(4), 409-416.

12 L. Appels, J. Lauwers, J. Degrève, L. Helsen, B. Lievens, K. Willems, J. Van Impe and R. Dewil, Anaerobic digestion in global bio-energy production: potential and research challenges, Renewable Sustainable Energy Rev., 2011, 15(9), 4295-4301.

13 M. P. Caporgno, M. Olkiewicz, A. Fortuny, F. Stüber, A. Fabregat, J. Font, J. Pruvost, O. Lepine, J. Legrand and C. Bengoa, Evaluation of different strategies to produce biofuels from Nannochloropsis oculata and Chlorella vulgaris, Fuel Process. Technol., 2016, 144, 132-138.

14 T. Rétfalvi, P. Szabó, A.-T. Hájos, L. Albert, A. Kovács, G. Milics, M. Neményi, E. Lakatos and V. Ördög, Effect of co-substrate feeding on methane yield of anaerobic digestion of Chlorella vulgaris, J. Appl. Phycol., 2016, 28(5), 2741-2752.

15 M. Wang, E. Lee, Q. Zhang and S. J. Ergas, Anaerobic codigestion of swine manure and microalgae Chlorella sp.: experimental studies and energy analysis, BioEnergy Res., 2016, 9(4), 1204-1215.

16 R. Li, N. Duan, Y. Zhang, Z. Liu, B. Li, D. Zhang and T. Dong, Anaerobic co-digestion of chicken manure and microalgae Chlorella sp.: methane potential, microbial diversity and synergistic impact evaluation, Waste Manage., 2017, 68, 120-127.

17 J. V. Oliveira, M. M. Alves and J. C. Costa, Design of experiments to assess pre-treatment and co-digestion strategies that optimize biogas production from macroalgae Gracilaria vermiculophylla, Bioresour. Technol., 2014, 162, 323-330.

18 H.-W. Yen and D. E. Brune, Anaerobic co-digestion of algal sludge and waste paper to produce methane, Bioresour. Technol., 2007, 98(1), 130-134.

19 S. Schwede, A. Kowalczyk, M. Gerber and R. Span, Anaerobic co-digestion of the marine microalga Nannochloropsis salina with energy crops, Bioresour. Technol., 2013, 148, 428-435.

$20 \mathrm{H}$. Zhu, A. Stadnyk, M. Béland and P. Seto, Co-production of hydrogen and methane from potato waste using a two-stage anaerobic digestion process, Bioresour. Technol., 2008, 99(11), 5078-5084.

21 D. Arapoglou, T. Varzakas, A. Vlyssides and C. Israilides, Ethanol production from potato peel waste (PPW), Waste Manage., 2010, 30(10), 1898-1902.

22 Y. Zhang, G. S. Caldwell, A. M. Zealand and P. J. Sallis, Anaerobic co-digestion of microalgae Chlorella vulgaris and potato processing waste: effect of mixing ratio, waste type and substrate to inoculum ratio, Biochem. Eng. J., 2019, 143, 91-100.

23 I. A. Nges, F. Escobar, X. Fu and L. Björnsson, Benefits of supplementing an industrial waste anaerobic digester with energy crops for increased biogas production, Waste Manage., 2012, 32(1), 53-59.

24 G. P. Da Silva, M. Mack and J. Contiero, Glycerol: a promising and abundant carbon source for industrial microbiology, Biotechnol. Adv., 2009, 27(1), 30-39.

25 Y. Mu, H. Teng, D.-J. Zhang, W. Wang and Z.-L. Xiu, Microbial production of 1,3-propanediol by Klebsiella pneumoniae using crude glycerol from biodiesel preparations, Biotechnol. Lett., 2006, 28(21), 1755-1759.

26 M. González-Pajuelo, J. C. Andrade and I. Vasconcelos, Production of 1, 3-propanediol by Clostridium butyricum VPI 3266 using a synthetic medium and raw glycerol, $J$. Ind. Microbiol. Biotechnol., 2004, 31(9), 442-446.

27 OECD/FAO, OECD-FAO agricultural outlook 2019-2028, Organisation for Economic Co-operation and Development, Paris, 2019, cited 2019 Sep 06, available from, http://www.fao.org/3/ca4076en/ca4076en.pdf.

28 S. Fernando, S. Adhikari, K. Kota and R. Bandi, Glycerol based automotive fuels from future biorefineries, Fuel, 2007, 86(17-18), 2806-2809.

29 A. C. Larsen, B. M. Gomes, S. D. Gomes, D. C. Zenatti and D. G. B. Torres, Anaerobic co-digestion of crude glycerin and starch industry effluent, Eng. Agric., 2013, 33(2), 341352.

30 S. T. Sell, D. R. Raman, R. Burns and R. P. Anex, Differing effects of glycerin on anaerobic co-digestion of mixed substrates in bench-scale assays and sub pilot-scale reactors, ASABE Annual International Meeting, 2011 Aug 710, American Society of Agricultural and Biological Engineers, Louisville, Kentucky, 2011, p. 1111519.

31 M. B. Viana, A. V. Freitas, R. C. Leitão, G. A. S. Pinto and S. T. Santaella, Anaerobic digestion of crude glycerol: a review, Environ. Technol. Rev., 2012, 1(1), 81-92.

32 O. Wohlgemut, N. Cicek, J. Oleszkiewicz and R. Sparling, Codigestion of hog manure with glycerol to boost biogas and methane production, Trans. ASABE, 2011, 54(2), 723-727.

33 S. Astals, V. Nolla-Ardèvol and J. Mata-Alvarez, Anaerobic codigestion of pig manure and crude glycerol at mesophilic conditions: biogas and digestate, Bioresour. Technol., 2012, 110, 63-70.

34 A. Serrano, J. A. Siles, A. F. Chica and M. A. Martin, Improvement of mesophilic anaerobic co-digestion of agrifood waste by addition of glycerol, J. Environ. Manage., 2014, 140, 76-82.

35 J. V. Oliveira, M. M. Alves and J. C. Costa, Optimization of biogas production from Sargassum sp. using a design of experiments to assess the co-digestion with glycerol and waste frying oil, Bioresour. Technol., 2015, 175, 480-485.

36 P. Neumann, A. Torres, F. G. Fermoso, R. Borja and D. Jeison, Anaerobic co-digestion of lipid-spent microalgae with waste activated sludge and glycerol in batch mode, Int. Biodeterior. Biodegrad., 2015, 100, 85-88.

37 I. Gifuni, A. Pollio, C. Safi, A. Marzocchella and G. Olivieri, Current bottlenecks and challenges of the microalgal biorefinery, Trends Biotechnol., 2019, 37(3), 242-252.

38 Y. Zhang, G. S. Caldwell and P. J. Sallis, Renewable energy: evaluation of low energy demand pre-treatments to 
optimise methane production from microalgae, IET Renew. Power Gener., 2019, 13(10), 1701-1710.

39 A. D. Eaton, L. S. Clesceri and A. E. Greenberg, Standard methods for the examination of water and wastewater, American Public Health Association, American Water Works Association, Water Environment Federation, Washington, DC, USA, 21st edn, 2005.

40 S. S. Nielsen, Food Analysis Laboratory Manual, Springer US, Boston, MA, 2010, pp. 47-53.

41 L. W. Jaroszynski, N. Cicek, R. Sparling and J. A. Oleszkiewicz, Impact of free ammonia on anammox rates (anoxic ammonium oxidation) in a moving bed biofilm reactor, Chemosphere, 2012, 88(2), 188-195.

42 U. Lossie and P. Pütz, Targeted control of biogas plants with the help of FOS/TAC: Practice Report, Hach-Lange, 2008.

43 M. C. Nelson, H. G. Morrison, J. Benjamino, S. L. Grim and J. Graf, Analysis, optimization and verification of Illuminagenerated 16S rRNA gene amplicon surveys, PloS One, 2014, 9(4), e94249.

44 J. J. Kozich, S. L. Westcott, N. T. Baxter, S. K. Highlander and P. D. Schloss, Development of a dual-index sequencing strategy and curation pipeline for analyzing amplicon sequence data on the MiSeq Illumina sequencing platform, Appl. Environ. Microbiol., 2013, 79(17), 5112-5120.

45 P. J. McMurdie and S. Holmes, phyloseq: an R package for reproducible interactive analysis and graphics of microbiome census data, PloS One, 2013, 8(4), e61217.

46 A. Field, Discovering statistics using SPSS, SAGE Publications, London, 3rd edn, 2009.

47 R. J. Ciotola, J. F. Martin, A. Tamkin, J. M. Castańo, J. Rosenblum, M. S. Bisesi and J. Lee, The influence of loading rate and variable temperatures on microbial communities in anaerobic digesters, Energies, 2014, 7(2), 785-803.

48 L. Pontoni, A. Panicob, E. Salzanoc, L. Frunzod, P. Iodiceb and F. Pirozzie, Innovative parameters to control the efficiency of anaerobic digestion process, Chem. Eng. Trans., 2015, 43, 2089-2094.

49 A. J. Ward, P. J. Hobbs, P. J. Holliman and D. L. Jones, Optimisation of the anaerobic digestion of agricultural resources, Bioresour. Technol., 2008, 99(17), 7928-7940.

50 M. E. Griffin, K. D. McMahon, R. I. Mackie and L. Raskin, Methanogenic population dynamics during start-up of anaerobic digesters treating municipal solid waste and biosolids, Biotechnol. Bioeng., 1998, 57(3), 342-355.

51 B. Calli, B. Mertoglu, B. Inanc and O. Yenigun, Methanogenic diversity in anaerobic bioreactors under extremely high ammonia levels, Enzyme Microb. Technol., 2005, 37(4), 448-455.

52 V. Moset, E. Bertolini, A. Cerisuelo, M. Cambra, A. Olmos and M. Cambra-López, Start-up strategies for thermophilic anaerobic digestion of pig manure, Energy, 2014, 74, 389395.

53 H. B. Nielsen, H. Uellendahl and B. K. Ahring, Regulation and optimization of the biogas process: propionate as a key parameter, Biomass Bioenergy, 2007, 31(11-12), 820830.
54 K. Xiao, Y. Zhou, C. Guo, Y. Maspolim and W.-J. Ng, Dynamics of propionic acid degradation in a two-phase anaerobic system, Chemosphere, 2015, 140, 47-53.

55 Y. Wang, Y. Zhang, J. Wang and L. Meng, Effects of volatile fatty acid concentrations on methane yield and methanogenic bacteria, Biomass Bioenergy, 2009, 33(5), 848-853.

56 M. S. Fountoulakis, I. Petousi and T. Manios, Co-digestion of sewage sludge with glycerol to boost biogas production, Waste Manage., 2010, 30(10), 1849-1853.

57 K. Panpong, G. Srisuwan, O. Sompong and P. Kongjan, Anaerobic co-digestion of canned seafood wastewater with glycerol waste for enhanced biogas production, Energy Procedia, 2014, 52, 328-336.

58 T. Nguyen, Biomethane potential test for rapid assessment of anaerobic digestion of sewage sludge: co-digestion with glycerol and trace organic removal, MPhil thesis, University of Wollongong, 2014.

59 J. Ma, M. Van Wambeke, M. Carballa and W. Verstraete, Improvement of the anaerobic treatment of potato processing wastewater in a UASB reactor by co-digestion with glycerol, Biotechnol. Lett., 2008, 30(5), 861-867.

60 E. S. Hernández, L. Travieso and P. Weiland, Anaerobic Digestion of Cattle Manure in Fixed Bed Reactor, in Environmental Biotechnology, ed. Young M. M., Anderson W. A. and Chakrabarty A. M., Springer, Dordrecht, 1995, pp. 588-597.

61 S. Sayed, W. de Zeeuw and G. Lettinga, Anaerobic treatment of slaughterhouse waste using a flocculant sludge UASB reactor, Agric. Wastes, 1984, 11(3), 197-226.

62 O. Yenigün and B. Demirel, Ammonia inhibition in anaerobic digestion: a review, Process Biochem., 2013, 48(5), 901-911.

63 H. B. Nielsen and I. Angelidaki, Strategies for optimizing recovery of the biogas process following ammonia inhibition, Bioresour. Technol., 2008, 99(17), 7995-8001.

64 Y.-F. Li, M. C. Nelson, P.-H. Chen, J. Graf, Y. Li and Z. Yu, Comparison of the microbial communities in solid-state anaerobic digestion (SS-AD) reactors operated at mesophilic and thermophilic temperatures, Appl. Microbiol. Biotechnol., 2015, 99(2), 969-980.

65 J. De Vrieze, M. E. Christiaens, D. Walraedt, A. Devooght, U. Z. Ijaz and N. Boon, Microbial community redundancy in anaerobic digestion drives process recovery after salinity exposure, Water Res., 2017, 111, 109-117.

66 J. De Vrieze, S. Gildemyn, R. Vilchez-Vargas, R. Jáuregui, D. H. Pieper, W. Verstraete and N. Boon, Inoculum selection is crucial to ensure operational stability in anaerobic digestion, Appl. Microbiol. Biotechnol., 2015, 99(1), 189-199.

67 J. De Vrieze, K. Plovie, W. Verstraete and N. Boon, Codigestion of molasses or kitchen waste with high-rate activated sludge results in a diverse microbial community with stable methane production, J. Environ. Manage., 2015, 152, 75-82. 
68 Y. Liu and W. B. Whitman, Metabolic, phylogenetic, and ecological diversity of the methanogenic archaea, Ann. N. Y. Acad. Sci., 2008, 1125(1), 171-189.

69 T. Kobayashi, D. Yasuda, Y.-Y. Li, K. Kubota, H. Harada and H.-Q. Yu, Characterization of start-up performance and archaeal community shifts during anaerobic selfdegradation of waste-activated sludge, Bioresour. Technol., 2009, 100(21), 4981-4988.

70 B. Tindall, The genus name Methanothrix Huser et al. 1983 and the species combination Methanothrix soehngenii Huser et al. 1983 do not contravene Rule 31a and are not to be considered as rejected names, the genus name Methanosaeta Patel and Sprott 1990 refers to the same taxon as Methanothrix soehngenii Huser et al. 1983 and the species combination Methanothrix thermophila Kamagata et al. 1992 is rejected: Supplementary information to Opinion 75. Judicial Commission of the International Committee on Systematics of Prokaryotes, Int. J. Syst. Evol. Microbiol., 2014, 64(10), 3597-3598.

71 C. Lin, P. Wu, Y. Liu, J. W. Wong, X. Yong, X. Wu, X. Xie, H. Jia and J. Zhou, Enhanced biogas production and biodegradation of phenanthrene in wastewater sludge treated anaerobic digestion reactors fitted with a bioelectrode system, Chem. Eng. J., 2019, 365, 1-9.
72 J. De Vrieze, T. Hennebel, N. Boon and W. Verstraete, Methanosarcina: the rediscovered methanogen for heavy duty biomethanation, Bioresour. Technol., 2012, 112, 1-9.

73 K. Lang, J. Schuldes, A. Klingl, A. Poehlein, R. Daniel and A. Brune, New mode of energy metabolism in the seventh order of methanogens as revealed by comparative genome analysis of "Candidatus Methanoplasma termitum", Appl. Environ. Microbiol., 2015, 81(4), 1338-1352.

74 T. Hori, S. Haruta, Y. Ueno, M. Ishii and Y. Igarashi, Dynamic transition of a methanogenic population in response to the concentration of volatile fatty acids in a thermophilic anaerobic digester, Appl. Environ. Microbiol., 2006, 72(2), 1623-1630.

75 M. K. Nobu, T. Narihiro, K. Kuroda, R. Mei and W.-T. Liu, Chasing the elusive Euryarchaeota class WSA2: genomes reveal a uniquely fastidious methyl-reducing methanogen, ISME J., 2016, 10(10), 2478-2487.

76 R. G. Saratale, G. Kumar, R. Banu, A. Xia, S. Periyasamy and G. D. Saratale, A critical review on anaerobic digestion of microalgae and macroalgae and co-digestion of biomass for enhanced methane generation, Bioresour. Technol, 2018, 262, 319-332.

77 C. Gonzalez-Fernandez, B. Sialve, N. Bernet and J. P. Steyer, Impact of microalgae characteristics on their conversion to biofuel. Part II: focus on biomethane production, Biofuels, Bioprod. Biorefin., 2012, 6(2), 205-218. 